\title{
Utility of dissolved Barium in distinguishing North American from Eurasian runoff in the Arctic Ocean
}

T. Roeske ${ }^{1 *}$, D. Bauch ${ }^{2}$, M. Rutgers v. d. Loeff ${ }^{1}$, B. Rabe ${ }^{1}$

${ }^{1}$ Alfred Wegener Institut für Polar- und Meeresforschung (AWI)

${ }^{2}$ Leibniz Institut für Meereswissenschaften an der Universität Kiel (IFM-GEOMAR)

*Corresponding author:

Tobias Roeske c/o Michiel Rutgers van der Loeff

Alfred Wegener Institute for Polar and Marine Research (AWI)

Am Handelshafen 12

27570 Bremerhaven, Germany

E-Mail: tobias.roeske@awi.de

Phone: +4947148311259

Fax: +49 47148311425 


\section{Abstract}

Dissolved barium has been shown to have the potential to distinguish Eurasian from North American (NA) river runoff. As part of the ARK-XXII/2 Polarstern expedition in summer 2007, Ba was analyzed in the Barents, Kara, Laptev seas, and the Eurasian Basins as well as the Makarov Basin up to the Alpha and Mendeleyev Ridges. By combining salinity, $\delta^{18} \mathrm{O}$ and initial phosphate corrected for mineralization with oxygen $\left(\mathrm{PO}_{4}{ }^{*}\right)$ or N/P ratios we identified the water mass fractions of meteoric water, sea ice meltwater, and marine waters of Atlantic as well as Pacific origin in the upper water column. In all basins inside the lower halocline layer and the Arctic intermediate waters we find $\mathrm{Ba}$ concentrations close to those of the Fram Strait branch of the lower halocline (41-45 nM), reflecting the composition of the incoming Atlantic water. A layer of upper halocline water (UHW) with higher Ba concentrations $(45-55 \mathrm{nM})$ is identified in the Makarov Basin. Atop of the UHW, the Surface Mixed Layer (SML), including the summer and winter mixed layers, has high concentrations of $\mathrm{Ba}(58-67 \mathrm{nM})$. In the SML of the investigated area of the central Arctic the meteoric fraction can be identified by assuming a conservative behavior of $\mathrm{Ba}$ to be primarily of Eurasian river origin. However, in productive coastal regions biological removal compromises the use of Ba to distinguish between Eurasian and NA rivers. As a consequence, the NA river water fraction is underestimated in productive surface waters or waters that have passed a productive region, whereas this fraction is overestimated in subsurface waters containing remineralised $\mathrm{Ba}$, particularly when these waters have passed productive shelf regions. Especially in the Laptev Sea and small regions in the Barents Sea, Ba concentrations are low in surface waters. In the Laptev Sea exceptionally high Ba concentrations in shelf bottom waters indicate that $\mathrm{Ba}$ is removed from surface waters to deep waters by biological activity enhanced by increasing ice-free conditions as well as by scavenging by organic matter of terrestrial origin. We interpret high Ba concentrations in the UHW of the Makarov Basin to result from enrichment by remineralisation in bottom waters on the shelf of the Chukchi Sea and therefore the calculated NA runoff is an artefact. We conclude that no NA runoff can be demonstrated unequivocally anywhere during our expedition with the set of tracers considered here. Small contributions of NA runoff may have been masked by Ba depletion and could only be resolved by supportive tracers on the uptake history. We thus suggest that Ba has to be used with care as it can put limits but not yield quantitative water mass distributions. Only if the extra $\mathrm{Ba}$ inputs exceed the cumulative biological uptake the signal can be unequivocally attributed to NA runoff.

Keywords: Barium; Arctic Ocean; biological cycling; surface water; GEOTRACES 


\section{Introduction}

The Arctic Ocean covers an area $9.6 \cdot 10^{6} \mathrm{~km}^{2}$ (Serreze et al., 2006) corresponding to $5 \%$ of the world oceans while it constitutes only $1.5 \%$ in volume (Guay and Falkner, 1998a). The shelves make out more than one third of this area. About $10 \%$ of the world's river discharge flows into the Arctic Ocean making it one of the most important estuarine systems (Aagaard and Carmack, 1989; Dickson et al., 2007). These rivers contribute to the fresh surface layer of the Arctic Ocean. Some part of the water from the $\mathrm{Ob}$ and Yenisey rivers enters the Laptev Sea through Wilkitsky Strait and merges with waters from the Lena River. This coastal current water is partly reflected northwards into the Canadian Basins in the East Siberian Sea (Guay et al., 2001). The Surface (summer) Mixed Layer (SML) in the Arctic Ocean is underlain by a winter mixed layer, with temperatures close to the freezing point of seawater, which in turn is overlying a thick halocline layer (Aagaard et al., 1981). The halocline is formed by local convective mixing and is also maintained by waters advected from the shelf seas. On the Canadian side of the Lomonosov Ridge a layer of upper halocline water (UHW) is characterized by a salinity of about 32.8 to 33.2 and a maximum in nutrients may be identified (Jones and Anderson, 1986; Morison et al., 1998). This UHW is partly composed of Pacific waters of winter origin which tend to enter the interior Arctic below the upper mixed layer because they are generally more saline (Coachman and Shigaev, 1992; Weingartner et al., 1998). Beneath the UHW a layer of lower halocline water (LHW) with salinity ranging from 34.2 to 34.4 has been identified (Jones and Anderson, 1986). These waters of Atlantic origin are divided further into a Barents Sea branch halocline and a Fram Strait branch halocline (Rudels et al., 2004). Below the halocline are a layer of Atlantic and Arctic intermediate waters as well as deep and bottom waters.

The marine biogeochemical behavior of $\mathrm{Ba}$ is described in detail in Falkner et al. (1993; 1994). Usually, dissolved Ba is linked closely to hard-part nutrients as alkalinity (reflecting $\mathrm{CaCO}_{3}$ ) and $\mathrm{Si}$, showing depletion in oceanic surface waters and enrichment in deep waters and along advective flow-lines (Chan et al., 1977; Falkner et al., 1993; Lea and Boyle, 1990). This distribution is primarily ascribed to the uptake of $\mathrm{Ba}$ in surface waters. As the mineral barite is being formed in microenvironments in intermediate waters, $\mathrm{Ba}$ is removed from the dissolved phase at these depths, sinking with fecal pellets and regenerates from the sediment (Bishop, 1988; Collier and Edmond, 1984; Dehairs et al., 1980; Dymond et al., 1992; Falkner et al., 1994; Guay and Falkner, 1998b). Barite formation may involve remineralization of acantharians which accumulate $\mathrm{Ba}$ in their $\mathrm{SrSO}_{4}$ skeleton (Bernstein et al., 1992; Bernstein et al., 1998). Furthermore barite formation is induced by diatoms accumulating $\mathrm{Ba}$ (Esser and Volpe, 2002). Rivers and hydrothermal venting are the main sources of Ba to the oceans (Edmond et al., 1979; Guay and Falkner, 1998a; Martin and Meybeck, 1979; Von Damm et al., 1985). Most hydrothermal Ba is thought to precipitate inorganically as barite in the vicinity of hot spring sources (Von Damm, 1990). In estuaries $\mathrm{Ba}$ is enriched by desorption from river-borne clays in exchange with the more abundant cations of seawater (Carroll et al., 1993; Falkner et al., 1993; Hanor and Chan, 1977; Li and Chan, 1979). Ba is highly enriched in North American (NA) rivers (Mackenzie) with respect to Eurasian rivers and typical Atlantic and Pacific surface waters (Cooper et al., 2008; Guay and Falkner, 1998b; Taylor et al., 2003). 
The strong salinity gradients between the different water masses result in a strong stratification especially in the Arctic Ocean surface layer. This is essential for the formation of sea ice and biological productivity in the ice-free areas. The largest freshwater inventory is found in the upper $300 \mathrm{~m}$ of the Canadian Basin (Rabe et al., 2009; Rabe et al., 2011; Yamamoto-Kawai et al., 2008). These waters are composed of Eurasian and NA river runoff, Pacific water modified in the Chukchi Sea, sea ice melt and net precipitation, insulating sea ice from the heat in the relatively warm Atlantic waters underneath (Björk and Söderkvist, 2002; Shimada et al., 2005). With its positive buoyancy this freshwater is one of the factors governing the formation of convective deep water in the North Atlantic and thus are of importance for the global ocean circulation and climate (Aagaard and Carmack, 1989; Guay et al., 2009). Based on salinity and oxygen isotopes, fractions of meteoric water, sea ice melt, and high salinity marine water may be discerned in surface waters (Bauch et al., 1995). The high salinity fraction can be divided in Atlantic and Pacific fractions by using initial phosphate corrected for mineralization with oxygen $\left(\mathrm{PO}_{4}{ }^{*}\right)$ (Broecker, 1985; Ekwurzel et al., 2001). Alternatively N/P ratios can be used to identify fractions of Atlantic or Pacific origin (Yamamoto-Kawai et al., 2008; Bauch et al., 2011a). Dissolved Ba was described previously as a powerful quasi-conservative tracer for Arctic water masses (Falkner et al., 1994; Guay and Falkner, 1998b; Taylor et al., 2003). This is true especially in the UHW $(<200 \mathrm{~m})$ and the SML of the Arctic Ocean where NA runoff with high $\mathrm{Ba}$ content can be distinguished from Eurasian runoff. In combination with other tracers of freshwater components (e.g. salinity, $\delta^{18} \mathrm{O}$, nutrients, ${ }^{228} \mathrm{Ra}$, fluorescence) it provides information on the riverine sources of meteoric water. However, the inclusion of $\mathrm{Ba}$ in the biogeochemical cycling of organic material implies that changes in productivity may impact its use as (semi

conservative) tracer. Indeed, Abrahamsen et al. (2009) suggest increasingly ice-free conditions to compromise the quantitative use of barium as a tracer of river water in the Arctic Ocean. This is strengthened by observations that $\mathrm{Ba}$ is released at depth from particles convecting down at the shelves' slopes, thus showing that biological uptake is of importance for its redistribution (Roeske et al., submitted).

In recent years, Arctic sea ice decline has risen from 2.2 to $3 \%$ per decade in 19791996 to about $10 \%$ in the last ten years (Comiso et al., 2008). Large areas especially on the shelves are free of sea ice for a prolonged time and the change in summer sea ice cover from 2006-2007, according to a model by Arrigo et al. (2008), may have caused an increase in primary production by $35 \mathrm{Tg}^{-1} \mathrm{y}^{-1}$. This results in higher carbon export on the shelves and has influence on Ba concentrations and thus its conservative behavior in the Arctic Ocean. We thus investigate to what extent recent changes in the Arctic have an impact on the utility of dissolved Ba to distinguish NA from Eurasian runoff.

\section{Methods}

In a companion paper (Roeske et al., submitted) from the same expedition we describe full depth profiles together with dissolved aluminium and silicate excluding surface water, while here we concentrate on the surface layer. Water samples were collected during Polarstern expedition ARK-XXII/2 in summer of 2007. The sampled area reaches from the Barents Sea to the Nansen Basin to the Kara Sea and then to the Makarov Basin and finally the Laptev Sea (Schauer, 2008) (table 1, fig. 1). There were 38 vertical profiles with about 450 samples (of which 246 are surface samples, table 2) for Ba (Pangaea data repository at http://doi.pangaea.de/10.1594/PANGAEA.758745, Roeske et al., 2011), using an 
ultra-clean Titanium-rosette with $12 \mathrm{~L}$ bottles from Royal NIOZ (De Baar et al., 2008). $15 \mathrm{ml}$ LDPE bottles were used to collect samples for $\mathrm{Ba}$. The bottles were pre-rinsed thrice with the water to be sampled. Unfiltered samples were acidified with $30 \mu \mathrm{l}$ quartz-distilled $\mathrm{HCl}$ and afterwards tightly sealed with parafilm and stored at room temperature. Samples from stations 228 through 246 were filtered onboard in a clean room container. In order to determine whether ultra-clean sampling is necessary for determination of $\mathrm{Ba}$, parallel samples were taken on the entire depth profile using the conventional AWI rosette at station 266. A further set of filtered samples was analyzed in 2009 from samples archived by the NIOZ team.

Ba was analyzed using an isotope dilution procedure (Falkner et al., 1993; Guay and Falkner, 1998b; Klinkhammer and Chan, 1990) and then measured with a ThermoFinnigan Element2 high resolution sector field inductively coupled plasma mass spectrometer (SF-ICP-MS). A ${ }^{135}$ Ba-enriched solution (produced from $\mathrm{BaCO}_{3}$ from Spex Industry) was calibrated using commercial ICP-MS standard solutions (Spetec $\circledR$ single element Ba for ICP-MS and NIST standard reference material ${ }^{\circledR}$ $1643 \mathrm{e}$ ). Aliquots of $500 \mu \mathrm{l}$ were spiked with this ${ }^{135} \mathrm{Ba}$-enriched solution to obtain a ${ }^{138} \mathrm{Ba} /{ }^{135} \mathrm{Ba}$ ratio between 0.7 to 1 to minimize error propagation (Klinkhammer and Chan, 1990) and diluted hundredfold using 18.2 M $\Omega$ water. Spiking and dilution were done gravimetrically. About $1 \mathrm{ml}$ of the samples were introduced via autosampler $(\sim 200 \mu \mathrm{l} / \mathrm{min}$ uptake) to a micro-concentric Teflon® nebulizer and an Apex® Q quartz desolvation chamber. The SF-ICP-MS was operated in peak jump mode and data were accumulated in three $20 \mathrm{~s}$ intervals for masses 135, 137, and 138. The SF-ICPMS was operated in low resolution mode $(\Delta \mathrm{m} \sim 300)$. A three minute wash-out with $1 \mathrm{M}$ double-distilled $\mathrm{HNO}_{3}$ was followed by a $90 \mathrm{sec}$. take-up time to make memory effects negligible. A blank and a monitor for mass-bias correction (Canadian certified reference material CRM NASS-5) bracketed every five samples. In addition, in every tray of 19 samples at least two standards were included to check consistency. Random repeats of two samples were also done in each run. Samples were analyzed twice. If duplicates varied by more than the calculated maximum method error, samples were prepared and analyzed anew. Sensitivity of the SF-ICP-MS resulted in about $200000 \mathrm{cps}{ }^{138} \mathrm{Ba}$ in samples of Atlantic background. Blanks always were below 2000 cps being usually below 1000 cps.

At station 266 profiles were taken on both the ultra-clean and the normal rosette and Ba results were equal within errors (cf. Roeske et al., 2011). At station 352 positioned in the Makarov Basin multiple samples were taken at a depth of $2000 \mathrm{~m}$ for interlab analyses (with two labs taking part using ICP-MS, including ours; at one lab analyses were done by ICP-MS and ICP-OES; at a fourth lab analyses were done by TIMS). The labs used different standards as absolute references for their ${ }^{135} \mathrm{Ba}$ solution. We noticed that calibration of our ${ }^{135} \mathrm{Ba}$ standard solution with commercial ICP-MS standard solutions (Spetec $®$ single element Ba for ICP-MS and NIST standard reference material ${ }^{\circledR} 1643 \mathrm{e}$ ) resulted in a concentration $7.2 \%$ higher than calibrations with the natural standard solutions SLRS-3 $(\mathrm{Ba}=13.4 \pm 0.6 \mu \mathrm{g} / \mathrm{L})$, SLRS-4 $(\mathrm{Ba}=$ $12.2 \pm 0.2 \mu \mathrm{g} / \mathrm{L})$, SLRS-5 $(\mathrm{Ba}=14.0 \pm 0.5 \mu \mathrm{g} / \mathrm{L})$, and OMP $(\mathrm{Ba}=10.4 \pm 0.2 \mu \mathrm{g} / \mathrm{L}$, an inhouse standard prepared by $\mathrm{C}$. Jeandel, LEGOS, Toulouse, France). The concentration was within errors of the other labs dependent on the method used for calibration. Using the commercial ICP-MS standards we were in agreement (within 0.9-5.5 \%) with the lab also using a commercial ICP-MS standard on a TIMS. Using the natural waters we agreed (within 0.3-2.6\%) with the other two labs doing the same on ICP-MS and ICP-OES. An additional interlab comparison (two labs, 
including ours) on samples of two different profiles resulted in correlations of 0.995 and $0.996\left(R^{2}\right)$ and slopes of 0.977 and 0.994 , respectively, also using natural waters as reference for the ${ }^{135} \mathrm{Ba}$ standard.

Taylor et al. (2003) discovered problems with the stoichiometry of the starting salts of commercial $\mathrm{BaCO}_{3}$ standards and thus used archived GEOSECS standards. We thus compared our data below the halocline layer (least influenced by short term processes) to other data in our sample area of the same year (Abrahamsen, personal communication), plotting Ba against salinity (fig. 2). Abrahamsen et al. (2009), chosen here for reference, use the same procedure previously used for all published data in the Arctic (cf. Falkner et al., 1993; 1994; Guay and Falkner, 1998b; 1998; Taylor et al., 2003). We found the best match (fig. 2) when using commercial standards. In order to keep in line with existing literature we decided to adopt that calibration procedure for the present study.

Ba concentrations were calculated following Klinkhammer and Chan (1990):

$$
[\mathrm{Ba}]\left(\mathrm{nmol} \cdot \mathrm{g}^{-1}\right)=\frac{\left(R_{m}-R_{\text {spk }}\right)\left[{ }^{135} \mathrm{Ba}\right] W_{\text {spk }}}{\left(1-\frac{R_{m}}{R_{\text {nat }}}\right) A_{138} W_{\text {sam }}}
$$

where $R_{m}=$ ratio measured, $R_{\text {nat }}=$ the naturally occurring ${ }^{138} \mathrm{Ba} /{ }^{135} \mathrm{Ba}$ mass ratio $\left(R_{\text {nat }}\right.$ $=10.877),{ }^{138} \mathrm{Ba} /{ }^{135} \mathrm{Ba}=$ ratio of the spike $\left(R_{\text {spk }}=0.025\right),{ }^{135} \mathrm{Ba}=$ the concentration of ${ }^{135} \mathrm{Ba}$ in the spike solution $\left(\left[{ }^{135} \mathrm{Ba}\right]=9.04 \mathrm{ppb}\right.$ and $9.53 \mathrm{ppb}$ in 2008 and 2009 respectively), $A_{138}=$ the natural abundance of ${ }^{138} \mathrm{Ba}\left(A_{138}=0.7166\right)$ and $W_{\text {sam }}$ and $W_{s p k}=$ the weights of the sample and the spike respectively.

Mass discrimination, called "mass bias", is derived by a method used by Freydier et al. (1995) by measuring the masses 135,137 , and 138 of a natural Ba solution (Canadian CRM NASS-5). It follows a linear law following eqn. 2:

$$
R_{m}=R_{t}(1+n \alpha)
$$

where $R_{m}=$ measured isotopic ratio, $R_{t}=$ true value of this isotopic ratio, $n=$ number of mass units between the two isotopes, and $\alpha=$ unitary mass discrimination. The recommended point and discrimination line are also given by Freydier et al. (1995).

Calculated maximum error of the method always was below $3 \%$. Precision of repeated analyses of samples and standard solutions was always within $1.5 \%(1-\sigma)$. The error of the ratio ${ }^{138} \mathrm{Ba} /{ }^{135} \mathrm{Ba}$ was $0.6 \%$ or better.

Salinity (conductivity), temperature and depth (pressure) were measured on two CTD's, one from the Netherlands Institute for Sea Research (NIOZ) and one from the Alfred Wegener Institute for Polar and Marine Research (AWI), Germany. Both were Sea Bird electronics and calibrated onboard (Schauer, 2008).

Water samples for stable oxygen isotope analysis were taken both with the ultraclean Titanium-rosette from Royal NIOZ as well as with the conventional AWI rosette. Oxygen isotopes were analyzed at the Leibniz Laboratory (Kiel, Germany) applying the $\mathrm{CO}_{2}$ - water isotope equilibration technique on at least 2 sub-samples on a Finnigan gas bench II unit coupled to a Finnigan DeltaPlusXL. The overall measurement precision for all $\delta^{18} \mathrm{O}$ analysis is $\pm 0.03 \%$ or smaller. The ${ }^{18} \mathrm{O} /{ }^{16} \mathrm{O}$ ratio is given versus VSMOW in the usual $\delta$-notation (Craig, 1961).

Figures were created using the Ocean Data View software (Schlitzer, 2010). 


\section{Results}

All $\mathrm{Ba}$ data are presented in table 2 and are also available on the Pangaea data base (Roeske et al., 2011). An overview of the elemental dissolved Ba distribution in the surface water layer of the sections is seen in figures 3-7a. Additional panels on water mass fractions together with $T_{\text {pot }}$ and salinity are displayed in Bauch et al. (2011a). Potential temperature and salinity data are courtesy of the oceanography group of ARKXXII/2 (Schauer, 2008). Ba concentrations of Atlantic origin, ranging from 41 to $45 \mathrm{nM}$, are characteristic throughout the investigated area (figs. 3-7a), especially inside of the LHW. Shelf bottom waters of the Laptev Sea have concentrations up to $96.6 \mathrm{nM}$ (fig. 7a), and in surface waters atop the UHW concentrations increase to $67 \mathrm{nM}$ towards the Canada Basin (fig. 5a). Concentrations lower than $40 \mathrm{nM}$ are found predominantly in surface waters of the Barents Sea. In surface waters of the Laptev Sea as well as in the Barents Sea at about $80^{\circ} \mathrm{N}$ low concentrations of 37.9 to $38.8 \mathrm{nM}$ and 30.3 to $31 \mathrm{nM}$ respectively are seen (figs. $3 \mathrm{a} \& 7 \mathrm{a}$ ).

The depth of the upper mixed layer was determined by density gradient from temperature and salinity profiles of 40 stations from July to September 2007. The total expedition included 185 stations, but only the stations where Ba data is available were considered. The SML is between 8 and $32 \mathrm{~m}$ thick, separated from underlying waters by a steep salinity gradient. A discontinuity and/ or gradient in the profiles of temperature and oxygen often coincided with the salinity gradient. Typical salinities in the SML range from about 27 to 31 on the Canadian side of the Lomonosov Ridge, 31 to 34 in the Eurasian Basins, 32 to 35 in the Barents Sea, and 29 to 33 in the Laptev Sea. Following Guay and Falkner (1998b) the UHW is defined by salinities from 32.5 to 33.5 and a nutrient maximum, while the LHW is taken to be the layer of salinities of 34 to 34.5 and a NO minimum. The UHW was found at a depth of 50 to $120 \mathrm{~m}$ and has a maximal thickness of $20 \mathrm{~m}$. In this layer Ba concentrations from 45.3 to $54.8 \mathrm{nM}$ are observed, close to Ba values found within this layer by Guay and Falkner (1998b). The LHW has a thickness of 20 to $100 \mathrm{~m}$ and can be traced over the whole area investigated at depths from 0 to $175 \mathrm{~m}$. Concentrations of Ba ranging from 41 to $47.7 \mathrm{nM}$ are found in the LHW. Guay and Falkner (1998b) found concentrations < $46 \mathrm{nM}$ in this layer. We found highest concentrations in the Canadian Basin and at station 400 at the Laptev Sea slope as well as one exceptionally high concentration of $51.6 \mathrm{nM}$ at station 385 in $100 \mathrm{~m}$ depth.

\subsection{Balancing the fresh water fraction in the upper water column}

The water mass fractions are calculated using a four-component system of mass balance equations based on salinity, $\delta^{18} \mathrm{O}$, and $\mathrm{PO}_{4}{ }^{*}$, a quasi-conservative tracer based on phosphate and dissolved oxygen (Broecker, 1985), using a method similar to that of Ekwurzel et al. (2001):

$$
\begin{aligned}
& f_{a}+f_{p}+f_{i}+f_{r}=1 \\
& f_{a} S_{a}+f_{p} S_{p}+f_{i} S_{i}+f_{r} S_{r}=S \\
& f_{a} \delta^{18} O_{a}+f_{p} \delta^{18} O_{p}+f_{i} \delta^{18} O_{i}+f_{r} \delta^{18} O_{r}=\delta^{18} O \\
& f_{a} P O_{4_{a}}^{*}+f_{p} P O_{4_{p}}^{*}+f_{i} P O_{4_{i}}^{*}+f_{r} P O_{4_{r}}^{*}=P O_{4}^{*}
\end{aligned}
$$

where $f_{a}$ is the Atlantic water fraction, $f_{p}$ is Pacific water, $f_{i}$ is sea ice melt (or ice formation if negative), and $f_{r}$ is meteoric water (neglecting precipitation this is river water). For further details on the fraction calculation refer also to Bauch et al. (2011a). If the resulting fraction of Pacific water is negative (because of vanishingly small quantities of Pacific water combined with small inaccuracies in end-members 
and measurements), a three-component system of equations is solved instead, only using eqns. 3 to 5 with $f_{p}$ set to zero (Östlund and Hut, 1984). Our end-members are following Ekwurzel et al. (2001) (table 3). The endmember for meteoric water is set to a $\delta^{18} \mathrm{O}$ of $-20 \%$ reflecting average meteoric waters in the Arctic Ocean (Bauch et al., 2010). Calculation of $\mathrm{PO}_{4}{ }^{*}$ by dissolved $\mathrm{O}_{2}$ is done assuming that the water is not in exchange with the atmosphere. While this is largely true under the winter sea ice cover, the Arctic Ocean is partly free of sea ice in summer and ice-free areas were especially large in summer 2007. Exchange of dissolved $\mathrm{O}_{2}$ with the atmosphere may lead to an underestimation of $f_{p}$ in the summer mixed layer (Bauch et al., 2011a). Bauch et al. (2011a) thus additionally follow the procedure based on N/P presented by Jones et al. (1998; 2008) and Yamamoto-Kawai et al. (2008) using the "pure Pacific water" correlation line $\left[\mathrm{NO}_{\mathrm{x}}\right]=15.314 \cdot\left[\mathrm{PO}_{4}\right]-14.395$ (Jones et al., 2008) and an adjusted "pure Atlantic water" correlation line (Bauch et al., 2011a) $\left[\mathrm{NO}_{\mathrm{x}}\right]=$ 16.785 $\left[\mathrm{PO}_{4}\right]-1.9126$. On the other hand denitrification creates an apparent $f_{p}$ signal and Bauch et al. (2011a) use the brine signal (negative fi) to identify this apparent $f_{p}$ within the Transpolar Drift. They conclude that within errors of the method, the N/Pbased $f_{p}$ signal observed at stations over the Lomonosov Ridge is entirely caused by denitrification on the Siberian shelves and is therefore an apparent $f_{p}$ signal. The N/Pbased method is therefore used on the Canadian side of the Lomonosov Ridge only while over the Ridge and in the Eurasian Basin we use the $\mathrm{PO}_{4}{ }^{*}$-based method.

We find varying fractions of meteoric water in the SML (figs. 3-7b, 6c). Largest $f_{r}$ within the Arctic Ocean basins with up to $19 \%$ are found in the Makarov Basin. In the Laptev Sea $f_{r}$ reaches $16 \%$ at our southernmost position and in sections $A$ and $B$ in the western part of the Eurasian Basin we find only up to $3 \%$ (see fig. 8b for integrated river water in the upper $50 \mathrm{~m}$ ). Sea ice meltwater and sea ice formation (negative fractions of sea ice meltwater) in the upper $50 \mathrm{~m}$ are shown in fig. $8 \mathrm{~d}$. While in the central Arctic Ocean net sea ice formation is dominant, in the western part of the Eurasian Basin close to the shelves we find large areas of net sea ice melt. Pacific waters are found to the east of $150^{\circ} \mathrm{E}$ only (fig. $8 \mathrm{c}$ ).

Because of the distinct end-member Ba concentrations of the NA and Eurasian river inputs to the Arctic Ocean (Falkner et al., 1994; Guay and Falkner, 1998b), and assuming in a first approximation a conservative behaviour of $\mathrm{Ba}$ we are able to solve a further system of mass balance equations (Guay et al., 2009):

$$
\begin{aligned}
& f_{E}+f_{N}=f_{r} \\
& f_{i} B a_{i}+f_{s} B a_{s}+f_{E} B a_{E}+f_{N} B a_{N}=B a \\
& \frac{f_{p}}{f_{a}+f_{p}} B a_{p}+\frac{f_{a}}{f_{a}+f_{p}} B a_{a}=B a_{s}
\end{aligned}
$$

where $f_{s}$ is the high-salinity water (Atlantic and Pacific) and $f_{E}$ and $f_{N}$ are the Eurasian and NA river runoff respectively. This allows us to distinguish Eurasian from NA runoff. We used end-member Ba concentrations by Guay et al. (2009) except for the Atlantic end-member, which is chosen from the core of the Atlantic water in the Nansen Basin of section A (see section 2, table 4). From this simple calculation we find fractions of NA runoff even in the Barents Sea bottom waters, which seems highly unlikely. Because we know that $\mathrm{Ba}$ is involved in biological processes we assume that this overestimation of $f_{N}$ is caused by Ba being exported to depths below $100 \mathrm{~m}$ where it is released by mineralisation and we thus correct waters inside or below the LHW to $f_{N}=0$. We then find NA runoff only in the central Arctic and Makarov Basin in the SML and in the Makarov Basin at depths from 50 to $100 \mathrm{~m}$ (fig. $6 \mathrm{c}$ ), with fractions of up to $2 \%$, which will be further discussed below (section 4.3 ). In 
all other areas we find that all river runoff is from Eurasian river input $f_{E}=f_{r}$ (figs. 3$5 b, 7 b)$.

\subsection{Biological activity and freshwater in the upper water column}

In the previous distinction of NA and Eurasian river water contributions we assumed that $\mathrm{Ba}$ behaves conservatively. However, depletion of $\mathrm{Ba}$ in surface waters and export to deeper waters in the Arctic have first been shown to occur in the Chukchi Sea by Falkner et al. (1994) and Coachman and Shigaev (1992) and Ba concentrations in surface waters were as low as $12 \mathrm{nM}$. Abrahamsen et al. (2009) derived the depletion of $\mathrm{Ba}$ from the water mass composition, but because we have no independent way to determine the fraction of NA river water, this procedure is only applicable for those areas where this fraction can be neglected. This is largely the case in the Eurasian basins where the Pacific water fraction $\mathrm{fp}$ is negligible and the presence of NA runoff therefore is very unlikely (cf. Taylor et al., 2003). In the Makarov Basin, where Pacific water is present in the surface water, we cannot a priori exclude the presence of NA runoff and we will consequently not apply calculation of $\mathrm{Ba}$ depletion here. For the other transects we calculate the depletion of $\mathrm{Ba}$ in the upper water column where we assume $f_{N}$ to be zero (section 3.1):

$$
\begin{aligned}
& B a^{0}=f_{a} B a_{a}+f_{p} B a_{p}+f_{i} B a_{i}+f_{E} B a_{E}+f_{N} B a_{N} \\
& B a_{d e p l}=\frac{B a^{0}-B a}{B a^{0}} \cdot 100
\end{aligned}
$$

where $\mathrm{Ba}^{0}$ is the expected $\mathrm{Ba}$ concentrations from the water mass fractions and the end-member concentrations (table 4). $B a_{d e p l}$ is the depletion then with positive and negative values reflecting depletion and enrichment [\%], respectively (figs. 3-5c, 7c). This has to be seen as a deficit or excess concentration of $\mathrm{Ba}$, based on the expected concentration $\mathrm{Ba}^{0}$. We find an enrichment of $\mathrm{Ba}$ in depths below 50 to $100 \mathrm{~m}$ close to the shelves (figs. 3-5c, 7c). Exceptionally large enrichment of $\mathrm{Ba}$ (values of $B a_{d e p}$ as low as $-61 \%$ ) is found in waters from below $20 \mathrm{~m}$ water depth in the Laptev Sea (fig. 7c). Depletion of Ba is found in surface waters up to $100 \mathrm{~m}$ in the whole area investigated (figs. 3-5c, 7c). Again we find the largest depletion in the Laptev Sea. Here we find Ba to be depleted by $31 \%$ in the SML. A similarly large depletion of up to $28 \%$ is found in the Barents Sea at about $80^{\circ} \mathrm{N}$ (fig. 3c). But depletion can also be seen in surface waters of the Amundsen Basin of section $\mathrm{C}$ and the Gakkel Ridge area of sections D, reaching $12 \%$ (figs. 5c \& 7c). Areas including NA runoff can be depleted as well with the underestimated American component being masked by uptake of $\mathrm{Ba}$.

\section{Discussion}

\subsection{Balancing the fresh water fraction in the upper water column}

The equivalent water column heights (i.e. integrated fractions) of meteoric water, sea ice melt and Pacific water in the upper $50 \mathrm{~m}$ (fig. 8) can be compared to results from the same year and region by Abrahamsen et al. (2009). Transects of Abrahamsen et al. (2009) on the Laptev shelf towards the Eurasian Basins were farther to the east, though: $125^{\circ} \mathrm{E}$ from $74^{\circ} \mathrm{N}$ to $80^{\circ} \mathrm{N}$ and $130^{\circ} \mathrm{E}$ from $74^{\circ} \mathrm{N}$ to $78^{\circ} \mathrm{N}$, instead of our $121^{\circ} \mathrm{E}, 75^{\circ} \mathrm{N}$ to $124^{\circ} \mathrm{E}, 79^{\circ} \mathrm{N}$ on section $\mathrm{D}$ (fig. 1). Cumulative river water heights in this area on our cruise range from 5 to $6 \mathrm{~m}$ in the Laptev Sea to about $3 \mathrm{~m}$ in the Eurasian Basins north of the shelf reproducing the data by Abrahamsen et al. (2009). We find large volumes of river water east of $90^{\circ} \mathrm{E}$ and north of $85^{\circ} \mathrm{N}$ (fig. 8a). In summer 2007 "onshore" atmospheric conditions prevailed in the Laotev Sea (Bauch et al., 2010). Such an "onshore" scenario forced by the prevailing wind patterns 
causes Eurasian river runoff from the Laptev Sea to flow preferably eastwards into the East Siberian Sea instead of leaving the shelf northwards (Guay et al., 2001; Dmitrenko et al., 2005; Zhang et al., 2008; Bauch et al., 2009, 2011b). In the East Siberian Sea these waters may mix with local shelf waters and Pacific water from the Bering Strait. Accordingly fractions of Pacific derived waters are found at the continental slope of the East Siberian Sea in summer 2007 (Abrahamsen et al.; 2009). Based on the mass balance equations (with corrected $f_{N}$, i.e., all negative values set to zero, see section 3.1) and disregarding as first approximation biological uptake we obtained fractions of Eurasian and NA runoff (figs. 3-7b \& 6c). The fraction of NA runoff in the Makarov Basin SML may be masked, however, as a result of the depletion/ uptake of Ba (Guay et al., 2009) observed in the SML of the shelves and the surface layer water of the Eurasian Basins (cf. sections 4.2, 4.3). Upon mineralization this results in an enrichment of $\mathrm{Ba}$ in deeper layers of water, where the fraction of NA runoff may thus be overestimated when using the five-component mass balance equations. Ba thus can be used as an indicator of biological uptake and release in areas where the abundance of NA runoff can be excluded. In areas potentially containing NA runoff, the effects of NA runoff and of biological cycling on the Ba mass balance cannot be distinguished without independent tracers. Without such additional tracers we are only able to give upper or lower limits regarding $f_{N}$. Guay et al. (2009) investigated river water components in the upper waters of the Canada Basin and detected NA runoff only in the Southern Canada Basin. Therefore it appears unlikely that the high Ba concentrations at about $100 \mathrm{~m}$ depth near the Alpha Ridge and Makarov Basin (fig. 6a) result from NA runoff as depicted in figure $6 \mathrm{c}$. Instead, we suggest that this signal is an overestimation caused by Ba inputs from mineralisation processes in bottom waters and sediments in the Chukchi Sea. These processes have been directly observed in our dataset on the Siberian shelves (Barents and Laptev seas), but may occure also further to the east e.g. on the Chukchi Sea shelf (Falkner et al., 1994; Guay and Falkner, 1998b).

\subsection{Biological activity and freshwater in the upper water column}

It is important for solving eqns. 7 and 8 to assume that the meteoric fraction is composed entirely of river water and that Ba behaves conservatively (Guay et al., 2009). Alteration of water by biological activities and/ or large amounts of direct precipitation may lead to inaccuracies. While neglecting precipitation cannot cause a large error, because of the comparably large input of continental runoff to the Arctic Ocean (Aagaard and Carmack, 1989; Dickson et al., 2007) neglecting biological activity is probably causing a significant error. High biological activity is seen especially in the Barents and Laptev seas during our expedition from high carbon export shown for both regions by Cai et al. (2010) using the ${ }^{234}$ Th method $(2.7$ and $2.9 \mathrm{mmol} \mathrm{m}^{-2} \mathrm{~d}^{-1}$, respectively). In the basins where the water was covered by sea ice very low export production was observed in $2007\left(0.2 \mathrm{mmol} \mathrm{m}^{-2} \mathrm{~d}^{-1}\right)$ and former years (Cai et al., 2010; Rutgers van der Loeff et al., 2002). Moreover Arrigo et al. (2008) estimate that primary production in 2007 was higher by $12.5-20.8 \mathrm{~mol} \mathrm{~m}^{-2} \mathrm{yr}^{-1}$ compared to 2006 in ice-free areas of the Siberian and Laptev sectors. In other icefree areas the increase in primary production was 2.1-6.2 $\mathrm{mol} \mathrm{m}^{-2} \mathrm{yr}^{-1}$ higher (Arrigo et al., 2008). Sea ice melt inventory ranges from about -2 to $1 \mathrm{~m}$ at the Laptev Sea continental margin in good agreement with Abrahamsen et al. (2009). Brine formation takes place mostly in the Laptev Sea and the central Arctic while in the western Eurasian Basins north of the Eurasian shelves we find net sea ice melt (fig. 8d). 
Large fractions of Pacific water are found in the Makarov Basin (fig. 8c). From figs. 3$5 \mathrm{c}$ and $7 \mathrm{c}$ we see that depletion of $\mathrm{Ba}$ is strongest in the central Eurasian Basins and in the Laptev and Barents seas. The depletion of $\mathrm{Ba}$ on the shelves is consistent with the geographic pattern of ${ }^{234} \mathrm{Th}$ export and thus of the calculated carbon export flux, revealing enhanced biological activity over the Arctic shelves (Cai et al., 2010). Over the central Arctic basin, however, these authors found ${ }^{234}$ Th to be near equilibrium with its parent ${ }^{238} U$ and concluded extremely low carbon export in the period 1-2 months before sampling in September 2007, which would suggest that there is no reduction of $\mathrm{Ba}$ by biological activity here. Nonetheless we find $\mathrm{Ba}$ to be depleted in the upper 100-150 m of the Nansen and Amundsen Basins. This indicates that these are advected waters from the Laptev Sea or from the Barents Sea branch of the lower halocline which have been altered by biological activity and depletion of $\mathrm{Ba}$ in the SML and enrichment below this depth (cf. Anderson et al., 2003). We can not, however, use the depletion of $\mathrm{PO}_{4}$ described by Anderson et al. (2003) for the years 1993-1997 to estimate the Ba depletion, because no depletion of $\mathrm{PO}_{4}$ is seen in the Eurasian Basins in our 2007 dataset.

In the Barents Sea a $28 \%$ depletion of Ba (fig. 3c) is accompanied by a pronounced salinity minimum in surface waters at about $80^{\circ} \mathrm{N}$ (cf. fig. 2a in Bauch et al., 2011a) accompanied by large net sea ice melt (fig. 8d). Just below that depth a pronounced maximum in chlorophyll concentration can be seen (cf. fig. 3 in Cai et al., 2010). This strongly suggests an origin from biological uptake at the ice edge. An elevation of $\mathrm{Ba}$ in deeper waters of the Barents Sea, which may have been caused by uptake of $\mathrm{Ba}$ into biogenic particles and release in deeper waters, is found only at station 239 with the strongest surface water depletion with $16 \%$ enrichment (values of $\mathrm{Ba}_{\text {depl }}-16 \%$ ) at $175 \mathrm{~m}$ depth (fig. 3c).

The large (though not total) depletion of Ba in surface waters of the Laptev Sea is associated with low salinity similar to the correlation of the depletion of Ba with low salinity in surface waters of the Barents Sea at about $80^{\circ} \mathrm{N}$ (cf. fig. 3b in Bauch et al., 2011a). At the same time, though, elevated Ba concentrations are encountered in deeper waters of the Laptev Sea. While the depletion in surface waters is about 26 to $31 \%$ of the expected concentration, $\mathrm{Ba}$ in shelf water of the Laptev Sea is elevated by up to $61 \%$ close to the bottom (fig. 7c). The gradient with depletion in the SML and enrichment in the underlying waters is exceptionally large. Abrahamsen et al. (2009) suggested biological export to be responsible, which is reasonable due to the patterns of ${ }^{234} \mathrm{Th}$ in the Laptev Sea (Cai et al., 2010). Moreover Anderson et al. (2009) have shown that in the Laptev Sea organic matter is dominantly of terrestrial origin and to a smaller degree of marine origin. In the Laptev Sea this terrigenous organic matter may thus have an important role in redistributing the elements by scavenging and/ or remineralization at depth, while autochtonous production is more important in the East Siberian Sea (Anderson, pers. comm.).

\subsection{Intrusions of Chukchi Sea water in the upper halocline}

In 100 m depth at station 342 positioned on the southern Alpha Ridge and neighboring stations 338 and 349 we find pronounced maxima of $\mathrm{Ba}$ (fig. 6a) and silicate (cf. fig. 11a in Middag et al., 2009) together with other nutrients (not shown). These maxima are found at the lower end of a maximum of the Pacific water fraction at 50 to $75 \mathrm{~m}$ water depth and these waters are identified by a salinity of 32.5 to 33.3 and their nutrient concentrations to be part of the UHW. At the lower end of the UHW at $120 \mathrm{~m}$ depth a pronounced minimum is seen in oxygen (fig. 9). Both could be 
explained by a layer of winter water from the bottom of the Chukchi Sea (cf. Woodgate et al., 2005) reaching into the Makarov Basin. These waters are enhanced in nutrients and reduced in oxygen by bacterial consumption of the summer bloom (Cooper et al., 1999; Walsh et al., 1989). While nutrients are released into the water column over the Chukchi shelf oxygen consumption is largest close to the bottom. Unfortunately there is no Ba data available at the depth of the oxygen minimum $(120 \mathrm{~m})$ but we expect high concentrations of $\mathrm{Ba}$, because in addition to release from biological particles $\mathrm{Ba}$ has also a source in sediments. Looking at the $\mathrm{Ba}$ and silicate (Middag et al., 2009) we see that this water with low oxygen and high $\mathrm{Ba}$ at the lower end of the UHW reaches far north into the Makarov Basin. In this water mass we calculate large fractions of NA runoff. As mentioned above (cf. 4.1) it is unlikely that this truly is NA runoff but rather water from the winter layer of the Chukchi Sea. Regardless of the Ba source we are able to identify water from the Chukchi shelf by support of other data (e.g. high silicate concentrations and high AOU) in depths of 50 to $100 \mathrm{~m}$ in the southern Makarov Basin and over the Alpha and Mendeleyev Ridges.

\section{Conclusions}

Dissolved $\mathrm{Ba}$ has to be used carefully as a tracer of river water sources because of its non-conservative behavior (Abrahamsen et al., 2009; Guay et al., 2009). Strong removal of 25 to $31 \%$ is observed over the Barents and Laptev shelves. On the Eurasian shelves terrestrial components have an important role in the vertical distribution of dissolved $\mathrm{Ba}$.

In the central Eurasian Basins we find surface waters depleted in $\mathrm{Ba}$ and close to the shelves Ba-enriched water below $100 \mathrm{~m} .{ }^{234}$ Th data show very low organic export in the basins in the 1-2 months preceding our sampling. The Ba depletion and enrichment may have been caused by biological activity older than the 1-2 months covered by the ${ }^{234}$ Th method, which means that it may well have been advected from the shelves. This implies that even in the central Arctic we would need additional parameters such as ${ }^{234} \mathrm{Th}$, nutrients, or oxygen to correct for these processes before we can use $\mathrm{Ba}$ to distinguish between American and Eurasian river waters. If in a seasonally less ice-covered or even ice-free Arctic Ocean primary production would increase the use of $\mathrm{Ba}$ as tracer for river sources would be even more questionable.

In the Makarov Basin enhanced Ba concentrations can be ascribed to Pacific water reaching as far as the Lomonosov Ridge, except for the southernmost stations at depths of about 50-100 m. We suggest that the alleged NA runoff in this area is a diagenetic signal originating in the Chukchi Sea winter layer instead. In agreement with Guay et al. (2009) Ba signals cannot unequivocally show the presence of NA river water anywhere in the area of our cruise.

Nonetheless export of $\mathrm{Ba}$ to bottom waters on the shelves allows us to track these waters in the central Arctic basins and the depletion of $\mathrm{Ba}$ in upper waters brings evidence of export by biological production. We finally assume that $\mathrm{Ba}$ as a tracer of river water stays important in areas covered by sea ice and thus low productivity.

\section{Acknowledgements}

This work has been funded by the EU Sixth Framework Programme DAMOCLES (Developing Arctic Modelling and Observing Capabilities for Long-term Environment Studies), contract number 018509GOCE. 
Also the good support by people from the IPY (International Polar Year) and the GEOTRACES program (international study of the global marine biogeochemical cycles of trace elements and their isotopes) has to be emphasized.

Special thanks go to Sabine Mertineit who helped in acquiring the Ba samples during Polarstern cruise ARK-XXII/2. We thank K. Bakker from nutrient department of Royal Netherlands Institute for Sea Research (NIOZ) for data on silicate and nutrients. Moreover we have to thank Prof. Hein De Baar from the $\mathrm{NIOZ}$ who made possible the access to their archived samples as well as Rob Middag and Maarten Klunder from the NIOZ for their cooperative help. We further thank A. Wisotzki from AWI oceanography group for supporting the oxygen data. D. Bauch was financially supported by the DFG under grant SP526/3.

We thank Catherine Jeandel, Erika Sternberg, Frank Dehairs, Kristin Orians and Yiming Luo for their participation in the interlab comparison and Kelly Falkner for helpful discussions on the calibration issue.

\section{References}

Aagaard, K. and Carmack, E.C., 1989. The Role of Sea Ice and Other Fresh-Water in the Arctic Circulation. Journal of Geophysical Research C: Oceans, 94(C10): 14485-14498, doi:10.1029/JC094iC10p14485.

Aagaard, K., Coachman, L.K., Carmack, E., 1981. On the Halocline of the Arctic Ocean. Deep-Sea Research Part I: Oceanographic Research Papers, 28(6): 529-545, doi:10.1016/0198-0149(81)90115-1.

Abrahamsen, E.P., Meredith, M.P., Falkner, K.K., Torres-Valdes, S., Leng, M.J., Alkire, M.B., Bacon, S., Laxon, S.W., Polyakov, I., Ivanov, V., 2009. Tracerderived freshwater composition of the Siberian continental shelf and slope following the extreme Arctic summer of 2007. Geophysical Research Letters, 36: 5 pp., doi:10.1029/2009gl037341.

Anderson, L. G., Jones, E. P., and Swift, J. H., 2003. Export production in the central Arctic Ocean evaluated from phosphate deficits. Journal of Geophysical Research C: Oceans, 108(3199): 6 pp., doi:10.1029/2001JC001057.

Anderson, L.G., Jutterström, S., Hjalmarsson, S., Wåhlström, I., Semiletov, I.P., 2009. Out-gassing of $\mathrm{CO}_{2}$ from Siberian Shelf seas by terrestrial organic matter decomposition. Geophysical Research Letters, 36(L20601): 6 pp., doi:10.1029/2009GL040046.

Arrigo, K.R., van Dijken, G., Pabi, S., 2008. Impact of a shrinking Arctic ice cover on marine primary production. Geophysical Research Letters, 35(L19603): 6 pp., doi:10.1029/2008GL035028.

Bauch, D., R. v. d. Loeff, M., Andersen, N., Torres-Valdes, S., Bakker, K. and Abrahamsen, E.P., 2011a. Origin of freshwater and polynya water in the Arctic Ocean halocline in summer 2007. Progress in Oceanography, doi:10.1016/j.pocean.2011.07.017.

Bauch, D., Gröger, M., Dmitrenko, I., Hölemann, J., Kirillov, S., Mackensen, A., Taldenkova, E., Andersen, N., 2011b. Atmospheric controlled freshwater release at the Laptev Sea Continental margin, Polar Research, 30: 58585871, doi:10.3402/polar.v30i0.5858.

Bauch, D., Hölemann, J., Willmes, S., Gröger, M., Novikhin, A., Nikulina, A., Kassens, H., Timokhov, L., 2010. Changes in distribution of brine waters on the Laptev Sea shelf in 2007. Journal of Geophysical Research, 115(C11008): 11 pp., doi:10.1029/2010JC006249. 
Bauch, D., Dmitrenko, I.A., Wegner, C., Hölemann, J.A., Kirillov, S.A., Timokhov, L.A., Kassens, H., 2009. Exchange of Laptev Sea and Arctic Ocean halocline waters in response to atmospheric forcing. Journal of Geophysical Research C: Oceans, 114(C05008): 8 pp., doi:10.1029/2008JC005062.

Bauch, D., Schlosser, P., Fairbanks, R.G., 1995. Freshwater balance and the sources of deep and bottom waters in the Arctic Ocean inferred from the distribution of $\mathrm{H}_{2}{ }^{18} \mathrm{O}$. Progress in Oceanography, 35(1): 53-80, doi:10.1016/0079-6611(95)00005-2.

Bernstein, R.E., Byrne, R.H., Betzer, P.R., Greco, A.M., 1992. Morphologies and transformations of celestite in seawater: The role of acantharians in strontium and barium geochemistry. Geochimica et Cosmochimica Acta, 56(8): 32733279, doi:10.1016/0016-7037(92)90304-2.

Bernstein, R.E., Byrne, R.H., Schijf, J., 1998. Acantharians: a missing link in the oceanic biogeochemistry of barium. Deep Sea Research Part I: Oceanographic Research Papers, 45(2-3): 491-505, doi:10.1016/S09670637(97)00095-2.

Bishop, J.K.B., 1988. The barite-opal-organic carbon association in oceanic particulate matter. Nature, 332(6162): 341-343, doi:10.1038/332341a0.

Björk, G. and Söderkvist, J., 2002. Dependence of the Arctic Ocean ice thickness distribution on the poleward energy flux in the atmosphere. Journal of Geophysical Research C: Oceans, 107(3173): 17 pp., doi:10.1029/2000jc000723.

Broecker, W.S., Takahashi, T., Takahashi, T., 1985. Sources and flow patterns of deep-ocean waters as deduced from potential temperature, salinity, and initial phosphate concentration. Journal of Geophysical Research, 90(C10): 69256939, doi:10.1029/JC090iC04p06925.

Cai, P., Rutgers van der Loeff, M., Stimac, I., Nöthig, E.-M., Lepore, K., Moran, S.B., 2010. Low export flux of particulate organic carbon in the central Arctic Ocean as revealed by 234Th:238U disequilibrium. Journal of Geophysical Research C: Oceans, doi:10.1029/2009JC005595.

Carroll, J., Falkner, K.K., Brown, E.T., Moore, W.S., 1993. The role of the GangesBrahmaputra mixing zone in supplying barium and ${ }^{226} \mathrm{Ra}$ to the Bay of Bengal. Geochimica et Cosmochimica Acta, 57(13): 2981-2990, doi:10.1016/00167037(93)90287-7.

Chan, L.H., Drummond, D., Edmond, J.M., Grant, B., 1977. On the barium data from the Atlantic GEOSECS expedition. Deep Sea Research, 24(7): 613-649, doi:10.1016/0146-6291(77)90505-7.

Coachman, L.K., Shigaev, V.V., 1992. Northern Bering-Chukchi Sea Ecosystem: The Physical Basis. In: P.A. Nagel (Editor), Results of the third joint US-USSR Bering \& Chukchi Seas expedition (BERPAC): Summer 1988. U.S. Fish and Wildlife Service, Washington, DC : pp. 17-27.

Collier, R., Edmond, J., 1984. The trace element geochemistry of marine biogenic particulate matter. Progress In Oceanography, 13(2): 113-199, doi:10.1016/0079-6611(84)90008-9.

Comiso, J.C., Parkinson, C.L., Gersten, R., Stock, L., 2008. Accelerated decline in Arctic sea ice cover. Geophysical Research Letters, 35(L01703): 6 pp., doi:10.1029/2007GL031972.

Cooper, L.W., Cota, G.F., Pomeroy, L.R., Grebmeier, J.M., Whitledge, T.E., 1999. Modification of NO, PO, and NO/PO during flow across the Bering and Chukchi shelves: Implications for use as Arctic water mass tracers. Journal of 
Geophysical Research C: Oceans, 104(C4): 7827-7836,

doi:10.1029/1999JC900010.

Cooper, L.W., McClelland, J.W., Holmes, R.M., Raymond, P.A., Gibson, J.J., Guay, C.K., Peterson, B.J., 2008. Flow-weighted values of runoff tracers (delta 180, DOC, Ba, alkalinity) from the six largest Arctic rivers. Geophysical Research Letters, 35(L18606): 5 pp., doi:10.1029/2008gl035007.

Craig, H., 1961. Standard for Reporting Concentrations of Deuterium and Oxygen-18 in Natural Waters. Science, 133(3467): 1833-1834, doi:10.1126/science.133.3467.1833.

De Baar, H.J.W., Timmermans, K.R., Laan, P., De Porto, H.H., Ober, S., Blom, J.J., Bakker, M.C., Schilling, J., Sarthou, G., Smit, M.G., Klunder, M., 2008. Titan: A new facility for ultraclean sampling of trace elements and isotopes in the deep oceans in the international Geotraces program. Marine Chemistry, 111(1-2): 4-21, doi:10.1016/j.marchem.2007.07.009.

Dehairs, F., Chesselet, R., Jedwab, J., 1980. Discrete suspended particles of barite and the barium cycle in the open ocean. Earth and Planetary Science Letters, 49(2): 528-550, doi:10.1016/0012-821X(80)90094-1.

Dickson, R., Rudels, B., Dye, S., Karcher, M., Meincke, J., Yashayaev, I., 2007. Current estimates of freshwater flux through Arctic and subarctic seas.

Progress in Oceanography, 73(3-4): 210-230, doi:10.1016/j.pocean.2006.12.003.

Dmitrenko, I., Kirillov, S., Eicken, H., Markova, N., 2005. Wind-driven summer surface hydrography of the eastern Siberian shelf. Geophysical Research Letters, 32(L14613): 5 pp., doi:10.1029/2005GL023022.

Dymond, J., Suess, E., Lyle, M., 1992. Barium in Deep-Sea Sediment: A Geochemical Proxy for Paleoproductivity. Paleoceanography, 7(2): 163-181, doi:10.1029/92PA00181.

Edmond, J.M., Measures, C., McDuff, R.E., Chan, L.H., Collier, R., Grant, B., Gordon, L.I., Corliss, J. B., 1979. Ridge crest hydrothermal activity and the balances of the major and minor elements in the ocean: The Galapagos data. Earth and Planetary Science Letters, 46(1): 1-18, doi:10.1016/0012821X(79)90061-X.

Ekwurzel, B., Schlosser, P., Mortlock, R.A., Fairbanks, R.G., Swift, J.H., 2001. River runoff, sea ice meltwater, and Pacific water distribution and mean residence times in the Arctic Ocean. Journal of Geophysical Research C: Oceans, 106(C5): 9075-9092.

Esser, B.K. and Volpe, A.M., 2002. At-sea high-resolution chemical mapping: extreme barium depletion in North Pacific surface water. Marine Chemistry, 79(2): 67-79, doi:10.1016/S0304-4203(02)00037-3.

Falkner, K.K., Klinkhammer, G.P., Bowers, T.S., Todd, J.F., Lewis, B.L., Landing, W.M., Edmond, J.M., 1993. The behavior of barium in anoxic marine waters. Geochimica et Cosmochimica Acta, 57(3): 537-554, doi:10.1016/00167037(93)90366-5.

Falkner, K.K., MacDonald, R.W., Carmack, E.C., Weingartner, T., 1994. The potential of barium as a tracer of Arctic water masses. In: O.M. Johannessen, R.D. Muench and J.E. Overland (Editors), The Polar Oceans and Their Role in Shaping the Global Environment: The Nansen Centennial Volume, AGU Geophysics Monograph Series. American Geophysical Union, Washington, DC, pp. 63-76.

Freydier, R., Dupré, B., Polve, M., 1995. Analyses by Inductively-Coupled PlasmaMass Spectrometry of Ba Concentrations in Water and Rock Samples - 
Comparison between Isotope-Dilution and External Calibration with or without Internal Standard. European Mass Spectrometry, 1(3): 283-291.

Guay, C.K. and Falkner, K.K., 1998a. A survey of dissolved barium in the estuaries of major Arctic rivers and adjacent seas. Continental Shelf Research, 18(8): 859882, doi:10.1016/S0278-4343(98)00023-5.

Guay, C.K. and Falkner, K.K., 1998b. Barium as a tracer of Arctic halocline and river waters. Deep-Sea Research Part II: Topical Studies in Oceanography, 44(8): 1543-1569, doi:10.1016/S0967-0645(97)00066-0.

Guay, C.K.H., Falkner, K.K., Muench, R.D., Mensch, M. Frank, M., Bayer, R., 2001. Wind-driven transport pathways for Eurasian Arctic river discharge. Journal of Geophysical Research C: Oceans, 106(C6): 11469-11480, doi:10.1029/2000JC000261.

Guay, C.K.H., McLaughlin, F.A., Yamamoto-Kawai, M., 2009. Differentiating fluvial components of upper Canada Basin waters on the basis of measurements of dissolved barium combined with other physical and chemical tracers. Journal of Geophysical Research C: Oceans, 114(C00A09): 17 pp., doi:10.1029/2008JC005099.

Hanor, J.S. and Chan, L.-H., 1977. Non-conservative behavior of barium during mixing of Mississippi River and Gulf of Mexico waters. Earth and Planetary Science Letters, 37(2): 242-250, doi:10.1016/0012-821X(77)90169-8.

Jones, E.P. and Anderson, L.G., 1986. On the Origin of the Chemical Properties of the Arctic Ocean Halocline. Journal of Geophysical Research C: Oceans, 91(C9): 10759-10767, doi:10.1029/JC091iC09p10759.

Jones, E., Anderson, L., and Swift, J., 1998. Distribution of Atlantic and Pacific water in the upper Arctic Ocean: Implications for circulation. Geophysical Research Letters, 25(6), 765-768.

Jones, E.P., Anderson, L.G., Jutterström, S., Mintrop, L., and Swift, J.H., 2008. Pacific freshwater, river water and sea ice meltwater across Arctic Ocean basins: Results from the 2005 Beringia Expedition. Journal of Geophysical Research, 113(C08012): 10 pp., doi:08010.01029/02007JC004124.

Klinkhammer, G.P. and Chan, L.H., 1990. Determination of barium in marine waters by isotope dilution inductively coupled plasma mass spectrometry. Analytica Chimica Acta, 232: 323-329, doi:10.1016/S0003-2670(00)81249-0.

Lea, D.W. and Boyle, E.A., 1990. Foraminiferal Reconstruction of Barium Distributions in Water Masses of the Glacial Oceans. Paleoceanography, 5(5): 719-742, doi:10.1029/PA005i005p00719.

Li, Y.-H. and Chan, L.-H., 1979. Desorption of Ba and ${ }^{226}$ Ra from river-borne sediments in the Hudson estuary. Earth and Planetary Science Letters, 43(3): 343-350, doi:10.1016/0012-821X(79)90089-X.

Martin, J.-M. and Meybeck, M., 1979. Elemental mass-balance of material carried by major world rivers. Marine Chemistry, 7(3): 173-206, doi:10.1016/03044203(79)90039-2.

Middag, R., de Baar, H.J.W., Laan, P., Bakker, K., 2009. Dissolved aluminium and the silicon cycle in the Arctic Ocean. Marine Chemistry, 115(3-4): 176-195, doi:10.1016/j.marchem.2009.08.002.

Morison, J., Steele, M., Andersen, R., 1998. Hydrography of the upper Arctic Ocean measured from the nuclear submarine USS Pargo. Deep-Sea Research Part I: Oceanographic Research Papers, 45(1): 15-38, doi:10.1016/S09670637(97)00025-3. 
Östlund, H.G. and Hut, G., 1984. Arctic Ocean Water Mass Balance from Isotope Data. Journal of Geophysical Research C: Oceans, 89(NC4): 6373-6381, doi:10.1029/JC089iC04p06373.

Rabe, B., Schauer, U., Mackensen, A., Karcher, M., Hansen, E., BeszczynskaMöller, A., 2009. Freshwater components and transports in the Fram Strait recent observations and changes since the late 1990s. Ocean Science, 5(3): 219-233, doi:10.5194/osd-6-581-2009.

Rabe, B., Karcher, M., Schauer, U., Toole, J. M., Krishfield, R. A., Pisarev, S., Kauker, F., Gerdes, R., Kikuchi, T., 2011. An assessment of Arctic Ocean freshwater content changes from the 1990s to the 2006-2008 period. Deep Sea Research Part I: Oceanographic Research Papers 58: 173-185 doi:10.1016/j.dsr.2010.12.002.

Roeske, T., Rutgers van der Loeff, M.M., Bauch, D., 2011. Barium measured on water bottle samples during POLARSTERN cruise ARK-XXII/2 (SPACE). http://doi.pangaea.de/10.1594/PANGAEA.758745.

Roeske, T., Middag, R., Bakker, K., Rutgers van der Loeff, M. M., submitted to Marine Chemistry. Deep water circulation and shelf water inputs to the Arctic Ocean by dissolved $\mathrm{Ba}$.

Rudels, B., Jones, E.P., Schauer, U., Eriksson, P., 2004. Atlantic sources of the Arctic Ocean surface and halocline waters. Polar Research, 23(2): 181-208, Doi:10.1111/j.1751-8369.2004.tb00007.x.

Rutgers van der Loeff, M.M., Meyer, R., Rudels, B., Rachor, E., 2002. Resuspension and particle transport in the Benthic Nepheloid Layer in and near Fram Strait in relation to faunal abundances and ${ }^{234}$ Th depletion. Deep-sea Research, 49(11): 1941-1958, doi:10.1016/S0967-0637(02)00113-9.

Schauer, U., 2008. The expedition ARKTIS-XXII/2 of the research vessel "Polarstern" in 2007. Berichte zur Polar- und Meeresforschung $=$ Reports on polar and marine research(579): $271 \mathrm{pp}$.

Schlitzer, R., 2010. Ocean Data View, http://odv.awi.de, latest access on March 30, 2011.

Serreze, M.C., Barrett, A.P., Slater, A.G., Woodgate, R.A., Aagaard, K., Lammers, R.B., Steele, M., Moritz, R., Meredith, M., Lee, C. M., 2006. The large-scale freshwater cycle of the Arctic. Journal of Geophysical Research C: Oceans, 111(C11010): 19 pp., doi:10.1029/2005JC003424.

Shimada, K., Itoh, M., Nishino, S., McLaughlin, F., Carmack, E., Proshutinsky, A., 2005. Halocline structure in the Canada Basin of the Arctic Ocean.

Geophysical Research Letters, 32(L03605): 5 pp., doi:10.1029/2004GL021358.

Taylor, J.R., Falkner, K.K., Schauer, U., Meredith, M., 2003. Quantitative considerations of dissolved barium as a tracer in the Arctic Ocean. Journal of Geophysical Research C: Oceans, 108(12): 4-1, doi:10.1029/2002JC001635.

Von Damm, K.L., 1990. Seafloor Hydrothermal Activity: Black Smoker Chemistry and Chimneys. Annual Review of Earth and Planetary Sciences, 18(1): 173-204, doi:10.1146/annurev.ea.18.050190.001133.

Von Damm, K.L., Edmond, J.M., Grant, B., Measures, C.I., Walden, B., Weiss, R.F., 1985. Chemistry of submarine hydrothermal solutions at $21^{\circ} \mathrm{N}$, East Pacific Rise. Geochimica et Cosmochimica Acta, 49(11): 2197-2220, doi:10.1016/0016-7037(85)90222-4.

Walsh, J.J., McRoy, C.P., Coachman, L.K., Goering, J.J., Nihoul, J.J., Whitledge, T.E., Blackburn, T.H., Parker, P.L., Wirick, C.D., Shuert, P. G., 1989. Carbon and nitrogen cycling within the Bering/Chukchi Seas: Source regions for 
organic matter effecting AOU demands of the Arctic Ocean. Progress In Oceanography, 22(4): 277-359, doi:10.1016/0079-6611(89)90006-2.

Weingartner, T.J., Cavalieri, D.J., Aagaard, K., Sasaki, Y., 1998. Circulation, dense water formation, and outflow on the northeast Chukchi shelf. Journal of Geophysical Research C: Oceans, 103(C4): 7647-7661.

Wisotzki, A (2008): Physical oceanography measured on water bottle samples during POLARSTERN cruise ARK-XXII/2. Alfred Wegener Institute for Polar and Marine Research, Bremerhaven, doi:10.1594/PANGAEA.759285.

Woodgate, R.A., Aagaard, K., Swift, J.H., Falkner, K.K., Smethie, W.M., Jr., 2005. Pacific ventilation of the Arctic Ocean's lower halocline by upwelling and diapycnal mixing over the continental margin. Geophysical Research Letters, 32(L18609): 5 pp., doi:10.1029/2005GL023999.

Yamamoto-Kawai, M., McLaughlin, F.A., Carmack, E.C., Nishino, S., Shimada, K., 2008. Freshwater budget of the Canada Basin, Arctic Ocean, from salinity, $\delta^{18} \mathrm{O}$, and nutrients. Journal of Geophysical Research C: Oceans, 113(C1): 12, doi:10.1029/2006JC003858.

Zhang, J.L., Lindsay, R., Steele, M., Schweiger, A., 2008. What drove the dramatic retreat of arctic sea ice during summer 2007? Geophysical Research Letters, 35(L11505): 5 pp., doi:10.1029/2008gl034005. 
Table 1: Station positions with Ba data available on ARK-XXII/2 in degrees latitude and longitude (first position of the station log).

\begin{tabular}{|c|c|c|c|c|c|c|c|}
\hline Section & Station & Lat. ${ }^{\circ} \mathrm{N}$ & Lon. ${ }^{\circ} \mathrm{E}$ & Section & Station & Lat. ${ }^{\circ} \mathrm{N}$ & Lon. ${ }^{\circ} \mathrm{E}$ \\
\hline \multirow[t]{8}{*}{$\overline{\mathrm{A}}$} & 228 & $75^{\circ} 0.03^{\prime}$ & $33^{\circ} 59.95^{\prime}$ & \multirow[t]{3}{*}{$\overline{C 1}$} & 306 & $85^{\circ} 55.37^{\prime}$ & $91^{\circ} 7.26^{\prime}$ \\
\hline & 236 & $77^{\circ} 30.04^{\prime}$ & $33^{\circ} 59.79^{\prime}$ & & 309 & $87^{\circ} 2.74^{\prime}$ & $104^{\circ} 47.21^{\prime}$ \\
\hline & 237 & $78^{\circ} 59.83^{\prime}$ & $33^{\circ} 59.68^{\prime}$ & & 310 & $87^{\circ} 39.46^{\prime}$ & $112^{\circ} 2.23^{\prime}$ \\
\hline & 239 & $80^{\circ} 59.69^{\prime}$ & $33^{\circ} 59.76^{\prime}$ & \multirow[t]{8}{*}{$\mathrm{C} 2$} & 316 & $88^{\circ} 10.58^{\prime}$ & $139^{\circ} 37.07^{\prime}$ \\
\hline & 246 & $81^{\circ} 52.10^{\prime}$ & $34^{\circ} 0.72^{\prime}$ & & 319 & $88^{\circ} 39.86^{\prime}$ & $153^{\circ} 39.66^{\prime}$ \\
\hline & 255 & $82^{\circ} 30.20^{\prime}$ & $33^{\circ} 57.12^{\prime}$ & & 326 & $88^{\circ} 1.71^{\prime}$ & $170^{\circ} 5.23^{\prime}$ \\
\hline & 258 & $83^{\circ} 59.93^{\prime}$ & $34^{\circ} 0.62^{\prime}$ & & 328 & $87^{\circ} 49.80^{\prime}$ & $-170^{\circ} 34.10^{\prime}$ \\
\hline & 260 & $84^{\circ} 29.36^{\prime}$ & $36^{\circ} 8.31^{\prime}$ & & 333 & $87^{\circ} 1.68^{\prime}$ & $-146^{\circ} 23.98^{\prime}$ \\
\hline \multirow[t]{5}{*}{$B$} & 261 & $84^{\circ} 38.72^{\prime}$ & $60^{\circ} 56.02^{\prime}$ & & 338 & $85^{\circ} 42.25^{\prime}$ & $-135^{\circ} 2.35^{\prime}$ \\
\hline & 266 & $83^{\circ} 8.27^{\prime}$ & $61^{\circ} 44.46^{\prime}$ & & 342 & $84^{\circ} 30.00^{\prime}$ & $-138^{\circ} 25.12^{\prime}$ \\
\hline & 271 & $82^{\circ} 30.18^{\prime}$ & $60^{\circ} 47.71^{\prime}$ & & 349 & $85^{\circ} 3.83^{\prime}$ & $-164^{\circ} 28.14^{\prime}$ \\
\hline & 272 & $82^{\circ} 15.12^{\prime}$ & $61^{\circ} 59.76^{\prime}$ & \multirow[t]{9}{*}{$\mathrm{D}$} & 371 & $84^{\circ} 39.19^{\prime}$ & $102^{\circ} 44.18^{\prime}$ \\
\hline & 276 & $82^{\circ} 5.05^{\prime}$ & $68^{\circ} 57.50^{\prime}$ & & 373 & $84^{\circ} 11.93^{\prime}$ & $108^{\circ} 56.10^{\prime}$ \\
\hline \multirow[t]{7}{*}{ C1 } & 279 & $81^{\circ} 14.71^{\prime}$ & $86^{\circ} 12.13^{\prime}$ & & 379 & $82^{\circ} 51.93^{\prime}$ & $117^{\circ} 49.73^{\prime}$ \\
\hline & 285 & $82^{\circ} 8.51^{\prime}$ & $86^{\circ} 19.75^{\prime}$ & & 382 & $81^{\circ} 21.45^{\prime}$ & $120^{\circ} 43.12^{\prime}$ \\
\hline & 291 & $82^{\circ} 42.61^{\prime}$ & $86^{\circ} 15.92^{\prime}$ & & 385 & $79^{\circ} 21.14^{\prime}$ & $124^{\circ} 21.63^{\prime}$ \\
\hline & 295 & $83^{\circ} 16.33^{\prime}$ & $86^{\circ} 16.97^{\prime}$ & & 389 & $78^{\circ} 21.30^{\prime}$ & $124^{\circ} 30.89^{\prime}$ \\
\hline & 299 & $84^{\circ} 3.06^{\prime}$ & $89^{\circ} 2.53^{\prime}$ & & 400 & $77^{\circ} 23.29^{\prime}$ & $123^{\circ} 24.02^{\prime}$ \\
\hline & 301 & $84^{\circ} 34.81^{\prime}$ & $89^{\circ} 50.14^{\prime}$ & & 407 & $76^{\circ} 10.83^{\prime}$ & $122^{\circ} 7.72^{\prime}$ \\
\hline & 302 & $84^{\circ} 53.56^{\prime}$ & $90^{\circ} 3.27^{\prime}$ & & 411 & $75^{\circ} 12.00^{\prime}$ & $121^{\circ} 21.45^{\prime}$ \\
\hline
\end{tabular}


Table 2: Dissolved Ba concentrations and methodical errors (Roeske et al., 2011), temperature, salinity, dissolved oxygen (courtesy of AWI oceanography group, Schauer et al., 2008) and phosphate (courtesy of nutrient department of Royal Netherlands Institute for Sea Research, Karel Bakker pers. comm.):

\begin{tabular}{|c|c|c|c|c|c|c|c|c|c|c|c|c|c|c|c|}
\hline Station & $\begin{array}{l}\text { depth } \\
\text { [m] }\end{array}$ & $\begin{array}{l}\mathrm{Ba} \\
{[\mathrm{nM}]}\end{array}$ & $\begin{array}{l}\text { error } \\
\text { [nM] }\end{array}$ & $\mathrm{T}\left[{ }^{\circ} \mathrm{C}\right]$ & Salinity & $\begin{array}{l}\mathrm{O}_{2} \\
{[\mu \mathrm{M}]}\end{array}$ & $\begin{array}{l}\mathrm{PO}_{4} \\
{[\mu \mathrm{M}]}\end{array}$ & Station & $\begin{array}{l}\text { depth } \\
\text { [m] }\end{array}$ & $\begin{array}{l}\mathrm{Ba} \\
{[\mathrm{nM}]}\end{array}$ & $\begin{array}{l}\text { error } \\
\text { [nM] }\end{array}$ & $\mathrm{T}\left[{ }^{\circ} \mathrm{C}\right]$ & Salinity & $\begin{array}{l}\mathrm{O}_{2} \\
{[\mu \mathrm{M}]}\end{array}$ & $\begin{array}{l}\mathrm{PO}_{4} \\
{[\mu \mathrm{M}]}\end{array}$ \\
\hline \multirow[t]{4}{*}{228} & 25.5 & 42.5 & 0.7 & 4.0787 & 35.0541 & 337.2 & 0.185 & \multirow[t]{4}{*}{306} & 50.3 & 45 & 0.7 & -1.8023 & 33.7654 & 335.2 & 0.427 \\
\hline & 49.4 & 42.8 & 0.8 & 2.7962 & 35.0909 & 323.5 & 0.672 & & 100.6 & 42.2 & 1.3 & -1.2953 & 34.2115 & 293.1 & 0.662 \\
\hline & 74.7 & 42.9 & 0.5 & 2.1408 & 35.0862 & 327.0 & 0.608 & & 150.6 & 41.7 & 1.2 & 0.0499 & 34.5286 & 284.6 & 0.751 \\
\hline & 100 & 43.6 & 0.8 & 1.1902 & 35.049 & 326.8 & 0.671 & & 200.6 & 42.1 & 0.8 & 1.0434 & 34.7767 & 279.1 & 0.82 \\
\hline \multirow[t]{7}{*}{236} & 4.7 & 40.1 & 0.7 & 2.6546 & 33.9547 & 327.8 & 0.051 & \multirow[t]{7}{*}{309} & 5.1 & 48.6 & 0.9 & -1.6876 & 31.7575 & 366.6 & 0.223 \\
\hline & 24.8 & 41.8 & 0.8 & -0.1154 & 34.2691 & 385.8 & 0.144 & & 25.2 & 51.3 & 0.7 & -1.6847 & 32.6497 & 351.6 & 0.355 \\
\hline & 50.6 & 44.2 & 0.8 & -1.57 & 34.5182 & 327.7 & 0.612 & & 50.2 & 49.5 & 0.8 & -1.7606 & 33.133 & 335.8 & 0.449 \\
\hline & 74.9 & 42.9 & 0.7 & -1.4798 & 34.5731 & 316.9 & 0.659 & & 75.3 & 44.7 & 0.8 & -1.6313 & 33.873 & 301.5 & 0.615 \\
\hline & 100.3 & 44.7 & 0.8 & 0.3147 & 34.7322 & 293.7 & 0.794 & & 100.6 & 43.9 & 1.2 & -1.2821 & 34.2176 & 295.3 & 0.651 \\
\hline & 125.6 & 43.4 & 0.8 & 1.1487 & 34.8809 & 301.9 & 9999 & & 148.4 & 42.3 & 1.2 & -0.0164 & 34.5275 & 288.6 & 0.727 \\
\hline & 150.5 & 43.9 & 0.7 & 1.6797 & 34.976 & 309.6 & 0.827 & & 200.6 & 44.7 & 0.7 & 1.041 & 34.7915 & 282.1 & 0.806 \\
\hline \multirow[t]{9}{*}{237} & 24.9 & 41.3 & 0.8 & -1.5191 & 34.2311 & 340.8 & 0.453 & \multirow[t]{6}{*}{310} & 8.9 & 57.8 & 0.9 & -1.6688 & 31.6038 & 371.7 & 0.187 \\
\hline & 50 & 41.6 & 0.9 & -1.5516 & 34.3294 & 319.0 & 0.557 & & 25 & 48.3 & 0.8 & -1.6529 & 31.9104 & 364.8 & 0.249 \\
\hline & 75.5 & 42.7 & 0.8 & -1.2634 & 34.453 & 315.1 & 0.615 & & 49.8 & 48.8 & 0.7 & -1.7348 & 32.7625 & 336.6 & 0.451 \\
\hline & 99.8 & 42.6 & 0.7 & -0.7816 & 34.537 & 310.5 & 0.655 & & 100 & 43.9 & 0.8 & -1.3112 & 34.2115 & 294.3 & 0.656 \\
\hline & 124.8 & 42.3 & 0.7 & 0.2784 & 34.6578 & 298.1 & 0.721 & & 150.1 & 41.9 & 1.2 & -0.0472 & 34.5106 & 287.9 & 0.72 \\
\hline & 150.3 & 43.5 & 0.8 & 0.7953 & 34.7228 & 291.0 & 0.766 & & 200.3 & 41.6 & 1.2 & 0.8723 & 34.7675 & 279.9 & 0.811 \\
\hline & 174.4 & 44.3 & 0.7 & 1.027 & 34.7663 & 286.8 & 0.804 & \multirow[t]{6}{*}{316} & 4.7 & 48.6 & 0.8 & -1.6764 & 31.1637 & 372.3 & 0.212 \\
\hline & 200 & 44.7 & 0.8 & 1.5849 & 34.8604 & 279.8 & 0.861 & & 24.9 & 51.6 & 1.3 & -1.6422 & 31.8107 & 350.7 & 0.402 \\
\hline & 225.6 & 44.2 & 1.1 & 1.4828 & 34.894 & 302.0 & 0.894 & & 49.9 & 51.3 & 1.2 & -1.7168 & 32.5013 & 327.2 & 0.559 \\
\hline \multirow[t]{8}{*}{239} & 4.6 & 30.3 & 0.8 & -0.9704 & 32.6638 & 388.4 & 0.044 & & 54 & 49.3 & 1.4 & -1.7102 & 32.6526 & 319.2 & 0.612 \\
\hline & 24.7 & 31 & 0.7 & -0.872 & 33.9182 & 370.1 & 0.148 & & 75.2 & 46.2 & 1.2 & -1.6032 & 33.8435 & 295.8 & 0.65 \\
\hline & 50.1 & 40.4 & 0.7 & -0.7108 & 34.3545 & 324.0 & 0.549 & & 100.2 & 44.5 & 1.4 & -1.3198 & 34.1767 & 292.8 & 0.691 \\
\hline & 75.2 & 43.4 & 0.8 & -0.2388 & 34.4803 & 309.8 & 0.679 & \multirow[t]{5}{*}{319} & 5 & 53.1 & 0.8 & -1.6356 & 30.424 & 375.5 & 0.293 \\
\hline & 100.3 & 44 & 0.7 & 0.5419 & 34.6237 & 297.8 & 0.765 & & 21.9 & 54.1 & 1 & -1.6281 & 30.5639 & 369.9 & 0.425 \\
\hline & 125 & 42.9 & 0.7 & 0.8113 & 34.6611 & 296.5 & 0.776 & & 50 & 54.8 & 1.3 & -1.7309 & 32.4774 & 327.9 & 0.604 \\
\hline & 148.2 & 43.3 & 0.7 & 0.8321 & 34.6674 & 297.3 & 0.784 & & 100.1 & 45.5 & 1.2 & -1.3708 & 34.116 & 289.0 & 0.689 \\
\hline & 175.2 & 50.3 & 0.7 & 0.8862 & 34.719 & 298.5 & 0.797 & & 200.8 & 43.4 & 1.2 & 0.5105 & 34.6732 & 276.0 & 0.823 \\
\hline \multirow[t]{3}{*}{246} & 4.4 & 39.3 & 0.7 & -1.3879 & 32.936 & 391.3 & 0.112 & \multirow[t]{3}{*}{326} & 9.6 & 59.9 & 0.8 & -1.5531 & 29.2911 & 365.3 & 0.459 \\
\hline & 24.7 & 41.9 & 0.8 & -1.5982 & 34.0838 & 327.0 & 0.587 & & 24.1 & 60.9 & 0.8 & -1.5328 & 30.3682 & 361.0 & 0.505 \\
\hline & 50.2 & 42.4 & 0.9 & -1.3636 & 34.3529 & 314.6 & 0.696 & & 75.3 & 48.4 & 1.3 & -1.6047 & 33.4606 & 283.1 & 0.782 \\
\hline
\end{tabular}




\begin{tabular}{|c|c|c|c|c|c|c|c|c|c|c|c|c|c|c|c|}
\hline & 100.2 & 42.3 & 0.7 & 2.0208 & 34.8279 & 288.0 & 0.796 & & 100.3 & 43.8 & 1.7 & -1.497 & 34.0318 & 283.6 & 0.702 \\
\hline & 200.7 & 42.3 & 0.9 & 2.7628 & 34.9903 & 285.6 & 0.824 & & 149.9 & 46.1 & 0.7 & -0.5068 & 34.4092 & 283.2 & 0.735 \\
\hline & 249.4 & 42.6 & 0.8 & 2.5975 & 34.9911 & 285.7 & 0.835 & & 200.1 & 49.5 & 1.2 & 0.3494 & 34.6481 & 275.3 & 0.814 \\
\hline \multirow[t]{4}{*}{255} & 18.6 & 42.2 & 1.1 & -1.6693 & 34.0832 & 307.8 & 0.563 & \multirow[t]{7}{*}{328} & 5 & 64.5 & 1 & -1.5387 & 28.9468 & 386.0 & 0.4 \\
\hline & 37.4 & 43 & 0.9 & -1.7694 & 34.2651 & 298.2 & 0.642 & & 24.6 & 61.4 & 2.7 & -1.5311 & 30.2788 & 378.9 & 0.448 \\
\hline & 98.1 & 43.1 & 0.7 & 1.9553 & 34.7919 & 276.0 & 0.795 & & 50 & 58.9 & 1.5 & -1.6435 & 31.1305 & 368.0 & 0.595 \\
\hline & 199.5 & 42.6 & 1.4 & 2.6914 & 34.9578 & 275.6 & 0.823 & & 75.6 & 50.5 & 5.8 & -1.6049 & 33.1995 & 299.5 & 0.96 \\
\hline \multirow[t]{5}{*}{258} & 4.5 & 41.8 & 0.8 & -1.6802 & 33.7842 & 343.0 & 0.399 & & 100.5 & 45.2 & 1.7 & -1.5229 & 33.9607 & 303.1 & 0.714 \\
\hline & 17.5 & 41.7 & 0.9 & -1.6993 & 34.0365 & 339.8 & 0.421 & & 150.3 & 43.2 & 0.8 & -0.5355 & 34.3968 & 300.2 & 0.748 \\
\hline & 40 & 42.1 & 0.8 & -1.8 & 34.1832 & 330.1 & 0.497 & & 200.6 & 44.3 & 1.3 & 0.301 & 34.6273 & 291.9 & 0.82 \\
\hline & 99.5 & 42.4 & 0.9 & -1.2023 & 34.3346 & 304.5 & 0.593 & \multirow[t]{6}{*}{333} & 7.8 & 60.3 & 0.7 & -1.5496 & 28.7277 & 373.4 & 0.532 \\
\hline & 200 & 45 & 1.2 & 2.0406 & 34.8827 & 275.7 & 0.853 & & 23.9 & 61.6 & 1 & -1.5379 & 28.8438 & 371.5 & 0.593 \\
\hline \multirow[t]{7}{*}{260} & 4.7 & 42.5 & 0.7 & -1.6723 & 33.8614 & 364.0 & 0.37 & & 49.4 & 59.8 & 1.2 & -1.5671 & 30.1146 & 351.6 & 0.921 \\
\hline & 24.4 & 42.3 & 0.8 & -1.7041 & 34.0272 & 364.1 & 0.374 & & 99.8 & 44.3 & 1.3 & -1.5395 & 33.9081 & 283.3 & 0.732 \\
\hline & 49.5 & 41 & 0.9 & -1.8189 & 34.1835 & 363.9 & 0.382 & & 149.8 & 43.1 & 0.7 & -0.7976 & 34.3575 & 285.6 & 0.722 \\
\hline & 74.3 & 42.2 & 0.9 & -1.8317 & 34.2029 & 354.7 & 0.442 & & 199.6 & 41.6 & 1.1 & 0.0491 & 34.5865 & 281.3 & 0.782 \\
\hline & 99.9 & 44.2 & 0.8 & -1.7668 & 34.2298 & 351.0 & 0.551 & \multirow[t]{7}{*}{338} & 5.3 & 62.1 & 0.8 & -1.535 & 28.585 & 373.0 & 0.807 \\
\hline & 149.7 & 42.1 & 1.3 & 1.2987 & 34.6852 & 343.6 & 0.521 & & 24.6 & 61.9 & 1.3 & -1.39 & 29.7106 & 375.9 & 0.858 \\
\hline & 200.1 & 42.7 & 1.2 & 2.0338 & 34.864 & 293.7 & 0.832 & & 50.3 & 59.4 & 1.5 & -1.5856 & 30.2997 & 370.1 & 0.942 \\
\hline \multirow[t]{6}{*}{261} & 4.1 & 42.2 & 0.8 & -1.5897 & 33.382 & 362.2 & 0.289 & & 75.2 & 61.9 & 1.2 & -1.5316 & 31.9056 & 292.2 & 1.576 \\
\hline & 25.4 & 42.9 & 0.8 & -1.697 & 33.9838 & 341.4 & 0.43 & & 100.7 & 53.1 & 0.9 & -1.4984 & 33.2897 & 263.0 & 1.102 \\
\hline & 50.2 & 42.2 & 0.8 & -1.8221 & 34.1618 & 328.9 & 0.509 & & 150.3 & 43.6 & 0.8 & -0.946 & 34.2266 & 282.3 & 0.769 \\
\hline & 75.6 & 42.8 & 0.8 & -1.8357 & 34.1843 & 325.8 & 0.53 & & 200 & 42.4 & 1.2 & -0.1259 & 34.5176 & 270.5 & 0.872 \\
\hline & 100.6 & 41.8 & 1.3 & -1.1429 & 34.279 & 307.2 & 0.667 & \multirow{7}{*}{342} & 10 & 58 & 0.9 & -1.4696 & 29.2901 & 377.7 & 0.824 \\
\hline & 201.2 & 42.3 & 0.7 & 2.2379 & 34.875 & 278.8 & 0.806 & & 25.2 & 59 & 1.2 & -1.4349 & 30.2968 & 381.8 & 0.841 \\
\hline \multirow[t]{5}{*}{$266 a$} & 3.8 & 40.6 & 0.8 & -1.641 & 33.3143 & 300.4 & 0.256 & & 50.5 & 59.1 & 1.3 & -1.5895 & 30.51 & 376.8 & 0.884 \\
\hline & 23.2 & 41.2 & 0.9 & -1.4261 & 33.7782 & 313.5 & 0.389 & & 75.5 & 61.2 & 1.2 & -1.5047 & 31.4757 & 318.6 & 1.559 \\
\hline & 50.1 & 43.5 & 1 & 1.3357 & 34.7015 & 279.0 & 0.741 & & 100.8 & 68 & 0.8 & -1.3774 & 32.5126 & 244.8 & 1.94 \\
\hline & 100.2 & 43.8 & 0.7 & 2.6667 & 34.9003 & 274.4 & 0.786 & & 150.6 & 45.1 & 1 & -1.1954 & 34.0809 & 281.4 & 0.78 \\
\hline & 199.8 & 45 & 1.3 & 2.6487 & 34.9565 & 276.5 & 0.807 & & 200.3 & 43.1 & 1.3 & -0.4155 & 34.4127 & 273.3 & 0.833 \\
\hline \multirow[t]{5}{*}{$266 b$} & 5 & 40.7 & 0.7 & -1.63 & 33.0568 & 378.4 & 0.179 & \multirow[t]{6}{*}{349} & 9.2 & 66.4 & 0.8 & -1.3983 & 26.9659 & 383.0 & 0.705 \\
\hline & 24.8 & 42.6 & 0.8 & -1.2084 & 34.1101 & 336.3 & 0.573 & & 24.9 & 66.5 & 1.2 & -1.4828 & 29.0032 & 386.8 & 0.723 \\
\hline & 49.8 & 44.3 & 0.7 & 1.1544 & 34.6408 & 307.9 & 0.733 & & 50.2 & 59.8 & 1.5 & -1.5414 & 31.1274 & 339.1 & 1.1 \\
\hline & 99.9 & 43.7 & 0.8 & 2.5363 & 34.8827 & 294.8 & 0.778 & & 75.1 & 55.2 & 1.3 & -1.5513 & 32.8902 & 291.3 & 1.096 \\
\hline & 199.9 & 44 & 1.4 & 2.7059 & 34.9623 & 298.3 & 0.802 & & 100.7 & 46.1 & 0.9 & -1.5422 & 33.869 & 298.0 & 0.775 \\
\hline 271 & 5 & 40.6 & 0.8 & -1.5182 & 32.8458 & 362.8 & 0.161 & & 150.3 & 44.1 & 0.8 & -0.6942 & 34.3371 & 297.5 & 0.76 \\
\hline
\end{tabular}




\begin{tabular}{|c|c|c|c|c|c|c|c|c|c|c|c|c|c|c|c|}
\hline 272 & 4.8 & 40.6 & 0.9 & -1.6348 & 32.6607 & 365.4 & 0.173 & & 200.6 & 42.7 & 1.3 & 0.1651 & 34.5988 & 291.9 & 0.817 \\
\hline \multirow[t]{8}{*}{276} & 5 & 42.3 & 0.8 & -1.692 & 32.9036 & 370.1 & 0.191 & \multirow[t]{6}{*}{371} & 9.5 & 47.2 & 0.7 & -1.689 & 33.1565 & 356.1 & 0.307 \\
\hline & 25.1 & 42.8 & 0.8 & -1.5777 & 33.814 & 342.5 & 0.469 & & 25.7 & 47.9 & 0.8 & -1.7623 & 33.4216 & 348.8 & 0.362 \\
\hline & 50.3 & 43.7 & 0.8 & -1.6347 & 34.3339 & 318.4 & 0.599 & & 50.1 & 46.7 & 0.9 & -1.8006 & 33.7238 & 339.0 & 0.417 \\
\hline & 74.6 & 43.8 & 0.5 & -0.4641 & 34.514 & 303.9 & 0.688 & & 74.3 & 44.8 & 0.8 & -1.6762 & 33.9225 & 310.9 & 0.612 \\
\hline & 102 & 43.1 & 0.8 & 1.8051 & 34.7945 & 288.7 & 0.742 & & 99.5 & 43.8 & 0.8 & -1.1617 & 34.2593 & 293.0 & 0.692 \\
\hline & 125.4 & 43.1 & 0.8 & 2.2314 & 34.8603 & 285.7 & 0.762 & & 150.7 & 42.4 & 1.2 & 0.1669 & 34.582 & 284.9 & 0.768 \\
\hline & 150.4 & 43.8 & 0.8 & 2.4824 & 34.9029 & 284.0 & 0.782 & \multirow[t]{6}{*}{373} & 10.5 & 49.1 & 0.9 & -1.7117 & 31.861 & 361.0 & 0.162 \\
\hline & 200.2 & 43.9 & 0.8 & 2.4144 & 34.9207 & 284.1 & 0.8 & & 24.2 & 50.9 & 0.8 & -1.674 & 32.6169 & 359.8 & 0.287 \\
\hline \multirow[t]{9}{*}{279} & 4.7 & 44.5 & 0.7 & -1.4967 & 32.6448 & 371.8 & 0.12 & & 50.5 & 45.1 & 0.7 & -1.7929 & 33.6733 & 334.7 & 0.421 \\
\hline & 25.5 & 43.5 & 0.8 & -1.6318 & 33.9438 & 358.2 & 0.498 & & 99.9 & 42.1 & 0.8 & -1.396 & 34.1908 & 294.5 & 0.67 \\
\hline & 50 & 42.8 & 0.7 & -0.7134 & 34.5466 & 328.3 & 0.659 & & 149.8 & 41.3 & 1.3 & 0.071 & 34.5336 & 286.9 & 0.743 \\
\hline & 74.9 & 43.2 & 0.7 & 0.8505 & 34.7568 & 314.8 & 0.749 & & 200.3 & 48.2 & 1.2 & 0.9584 & 34.7818 & 279.9 & 0.834 \\
\hline & 100.8 & 44.9 & 0.7 & 1.2518 & 34.8443 & 309.6 & 0.787 & \multirow[t]{6}{*}{379} & 9.2 & 45.2 & 0.7 & -1.6622 & 31.1065 & 352.0 & 0.152 \\
\hline & 124.4 & 43.1 & 0.8 & 1.1389 & 34.8747 & 308.8 & 0.809 & & 24.4 & 46.4 & 0.8 & -1.6798 & 32.6984 & 348.3 & 0.322 \\
\hline & 150.4 & 45.8 & 0.8 & 0.8942 & 34.8802 & 310.2 & 0.809 & & 50.3 & 43.8 & 0.7 & -1.7277 & 33.484 & 316.6 & 0.555 \\
\hline & 200.6 & 43.3 & 1.3 & -0.6652 & 34.8056 & 329.2 & 0.738 & & 100 & 41.4 & 0.8 & -1.0232 & 34.2814 & 294.8 & 0.663 \\
\hline & 250.1 & 44.2 & 0.6 & -0.7638 & 34.8481 & 333.2 & 0.719 & & 149.1 & 44.5 & 1.3 & 0.5095 & 34.6333 & 284.1 & 0.763 \\
\hline \multirow[t]{7}{*}{285} & 9.1 & 43.1 & 0.8 & -1.6248 & 32.5168 & 356.5 & 0.209 & & 200.2 & 41.2 & 1.2 & 1.169 & 34.8267 & 279.3 & 0.835 \\
\hline & 24.3 & 42.8 & 0.8 & -1.5651 & 33.2454 & 350.1 & 0.288 & \multirow[t]{7}{*}{382} & 10.2 & 46.4 & 0.7 & -1.6545 & 31.2707 & 349.6 & 0.142 \\
\hline & 49.8 & 41.2 & 0.8 & -0.951 & 34.3039 & 314.5 & 0.582 & & 24.9 & 48.9 & 0.8 & -1.669 & 32.6921 & 340.9 & 0.378 \\
\hline & 75.1 & 42 & 0.8 & -1.7517 & 34.4288 & 314.4 & 0.551 & & 50 & 44.4 & 0.7 & -1.6787 & 33.8547 & 302.0 & 0.582 \\
\hline & 100.4 & 43.1 & 1.2 & -1.4458 & 34.4855 & 307.8 & 0.602 & & 75.4 & 43.4 & 0.8 & -1.3598 & 34.1941 & 294.1 & 0.66 \\
\hline & 200 & 45.6 & 1.2 & 1.1118 & 34.8147 & 292.6 & 0.761 & & 100.9 & 43.2 & 1.3 & -0.6064 & 34.3761 & 290.1 & 0.698 \\
\hline & 250.3 & 41.7 & 1.4 & 1.36 & 34.8696 & 291.5 & 0.794 & & 149.7 & 43 & 1.3 & 0.6357 & 34.6692 & 280.7 & 0.798 \\
\hline \multirow[t]{6}{*}{291} & 8.5 & 39.4 & 0.8 & -1.6423 & 33.1259 & 364.2 & 0.274 & & 200.1 & 42.8 & 1.2 & 1.1987 & 34.8316 & 277.3 & 0.881 \\
\hline & 24.7 & 40 & 0.8 & -1.7357 & 34.0576 & 321.2 & 0.486 & \multirow[t]{7}{*}{385} & 1 & 42.8 & 0.7 & -0.9681 & 31.2057 & 345.5 & 0.098 \\
\hline & 49.7 & 40.2 & 0.7 & -1.7959 & 34.1197 & 314.3 & 0.548 & & 25.3 & 44.7 & 0.8 & -1.6786 & 33.8141 & 332.9 & 0.377 \\
\hline & 99.3 & 40.6 & 0.7 & 2.1692 & 34.7432 & 283.2 & 0.759 & & 49.5 & 43.7 & 0.9 & -1.7919 & 33.9876 & 325.0 & 0.44 \\
\hline & 150.2 & 42.6 & 1.3 & 3.0943 & 34.9449 & 279.0 & 0.806 & & 74.8 & 43 & 0.8 & -1.4419 & 34.1913 & 303.1 & 0.606 \\
\hline & 200.6 & 41.1 & 0.8 & 2.9297 & 34.949 & 279.4 & 0.825 & & 100.9 & 51.6 & 1.3 & -0.5913 & 34.3882 & 292.4 & 0.679 \\
\hline \multirow[t]{5}{*}{295} & 9.7 & 41.2 & 0.7 & -1.6476 & 33.3319 & 347.7 & 0.356 & & 150.4 & 43.2 & 1.2 & 1.7108 & 34.7925 & 280.1 & 0.807 \\
\hline & 29 & 41.1 & 0.7 & -1.642 & 33.9985 & 341.8 & 0.4 & & 200.9 & 43.8 & 0.8 & 2.2456 & 34.9106 & 278.8 & 0.837 \\
\hline & 50 & 43.6 & 0.9 & -1.7553 & 34.1796 & 328.7 & 0.503 & \multirow[t]{3}{*}{389} & 9.6 & 46.7 & 0.7 & -0.0897 & 31.4661 & 342.2 & 0.233 \\
\hline & 114 & 43.2 & 1.2 & 0.817 & 34.5455 & 292.2 & 0.712 & & 24 & 47.4 & 0.9 & -1.6203 & 33.4685 & 334.2 & 0.435 \\
\hline & 149.9 & 41.1 & 1.2 & 2.7128 & 34.8716 & 279.3 & 0.779 & & 50.8 & 44.2 & 0.7 & -1.7382 & 34.023 & 318.1 & 0.483 \\
\hline
\end{tabular}




\begin{tabular}{|c|c|c|c|c|c|c|c|c|c|c|c|c|c|c|c|}
\hline & 199.5 & 43 & 1.3 & 2.8677 & 34.9393 & 279.1 & 0.808 & & 76.3 & 43.8 & 0.7 & -1.6317 & 34.2016 & 310.9 & 0.546 \\
\hline \multirow[t]{6}{*}{299} & 8.3 & 42.7 & 0.8 & -1.6869 & 32.7296 & 346.0 & 0.313 & & 99.8 & 43.9 & 0.8 & -1.1191 & 34.3493 & 303.6 & 0.62 \\
\hline & 24.2 & 43.8 & 0.9 & -1.629 & 33.3818 & 344.2 & 0.359 & & 149.7 & 43.1 & 1.3 & 1.0584 & 34.6955 & 285.8 & 0.754 \\
\hline & 50.2 & 43.8 & 0.8 & -1.776 & 34.0915 & 327.7 & 0.482 & & 200.1 & 42.8 & 1.2 & 1.8562 & 34.8463 & 280.5 & 0.804 \\
\hline & 74.1 & 42.9 & 0.7 & -1.674 & 34.1898 & 319.5 & 0.551 & & 249.7 & 43.5 & 0.7 & 1.928 & 34.8854 & 280.2 & 0.823 \\
\hline & 100 & 44.1 & 0.8 & -1.6527 & 34.2548 & 319.1 & 0.574 & \multirow[t]{7}{*}{400} & 10.4 & 50.4 & 0.7 & -1.5047 & 32.352 & 368.2 & 0.221 \\
\hline & 200.5 & 41.7 & 0.9 & 1.6627 & 34.8274 & 280.0 & 0.821 & & 26.8 & 47.5 & 0.7 & -1.3892 & 33.719 & 323.9 & 0.552 \\
\hline \multirow[t]{6}{*}{301} & 5.6 & 43.7 & 0.8 & -1.6453 & 33.3433 & 353.8 & 0.282 & & 50.7 & 46.5 & 0.7 & -1.3453 & 34.2078 & 315.1 & 0.627 \\
\hline & 25.1 & 44.1 & 0.8 & -1.6839 & 33.653 & 344.4 & 0.364 & & 75.6 & 45.3 & 0.8 & -1.5371 & 34.3736 & 321.9 & 0.622 \\
\hline & 50.6 & 43.1 & 0.7 & -1.8089 & 34.0067 & 327.5 & 0.462 & & 101.2 & 45.9 & 1.2 & -1.6239 & 34.417 & 322.8 & 0.635 \\
\hline & 100.3 & 41.8 & 1.2 & -0.8609 & 34.3054 & 292.3 & 0.676 & & 151.2 & 44.3 & 1.2 & 0.0761 & 34.6224 & 309.4 & 0.699 \\
\hline & 149.6 & 41 & 1.3 & 0.8427 & 34.6427 & 282.3 & 0.769 & & 201.5 & 42.9 & 0.8 & 1.7387 & 34.8423 & 302.1 & 0.768 \\
\hline & 200.5 & 42.1 & 0.8 & 1.8189 & 34.8386 & 279.3 & 0.821 & \multirow[t]{3}{*}{407} & 10.1 & 38.8 & 0.7 & -0.1166 & 29.7169 & 350.5 & 0.131 \\
\hline \multirow[t]{5}{*}{302} & 25 & 46.1 & 0.8 & -1.6932 & 33.6021 & 346.3 & 0.365 & & 30.3 & 54.9 & 1.1 & -1.5977 & 33.4605 & 325.3 & 0.47 \\
\hline & 39.6 & 44.8 & 1.8 & -1.7733 & 33.8362 & 337.9 & 0.427 & & 55.9 & 54.6 & 0.7 & -1.6241 & 33.806 & 277.0 & 0.716 \\
\hline & 47.1 & 45.4 & 0.8 & -1.7774 & 33.9365 & 333.8 & 0.455 & \multirow[t]{5}{*}{411} & 9.8 & 37.9 & 0.8 & 0.531 & 29.1174 & 350.4 & 0.169 \\
\hline & 100.5 & 41.8 & 1.3 & -0.8102 & 34.3212 & 293.7 & 0.698 & & 14.8 & 50.1 & 0.8 & 1.1734 & 30.688 & 336.8 & 0.435 \\
\hline & 200.5 & 41.8 & 0.9 & 1.4429 & 34.8255 & 281.1 & 0.848 & & 20 & 96.6 & 0.7 & 0.4715 & 32.5005 & 309.3 & 0.555 \\
\hline \multirow[t]{2}{*}{306} & 5.3 & 47.5 & 0.7 & -1.6797 & 32.3133 & 360.1 & 0.263 & & 25.2 & 96.6 & 0.8 & 0.462 & 32.5024 & 310.5 & 0.533 \\
\hline & 24.4 & 45.8 & 0.8 & -1.6919 & 33.4738 & 344.3 & 0.388 & & 35.3 & 93.6 & 0.7 & 0.0057 & 32.6585 & 304.7 & 0.548 \\
\hline
\end{tabular}

Table 3: Parameters used in three-component and four-component mass balance following Ekwurzel et al. (2001).

\begin{tabular}{|l|l|l|l|}
\hline & $\mathbf{P O}_{4}{ }^{*}\left[\mathbf{\mu m o l} \cdot \mathbf{k g}^{-1}\right]$ & $\delta^{18} \mathbf{O}[\% \mathrm{o}]$ & Salinity \\
\hline Atlantic water & 0.7 & 0.3 & 34.92 \\
River runoff & 0.1 & -20 & 0 \\
Sea ice & 0.4 & surface +2.6 & 4 \\
Pacific water & 2.4 & -1.1 & 32.7 \\
\hline
\end{tabular}

Table 4: End-member concentrations of Ba based on Guay et al. (2009).

\begin{tabular}{|ll|}
\hline & Ba [nM] \\
\hline Atlantic water & $43 \pm 3$ \\
Pacific water & $55 \pm 5$ \\
Sea ice & $5 \pm 1$ \\
Eurasian runoff & $130 \pm 15 \%$ \\
NA runoff & $520 \pm 15 \%$ \\
\hline
\end{tabular}




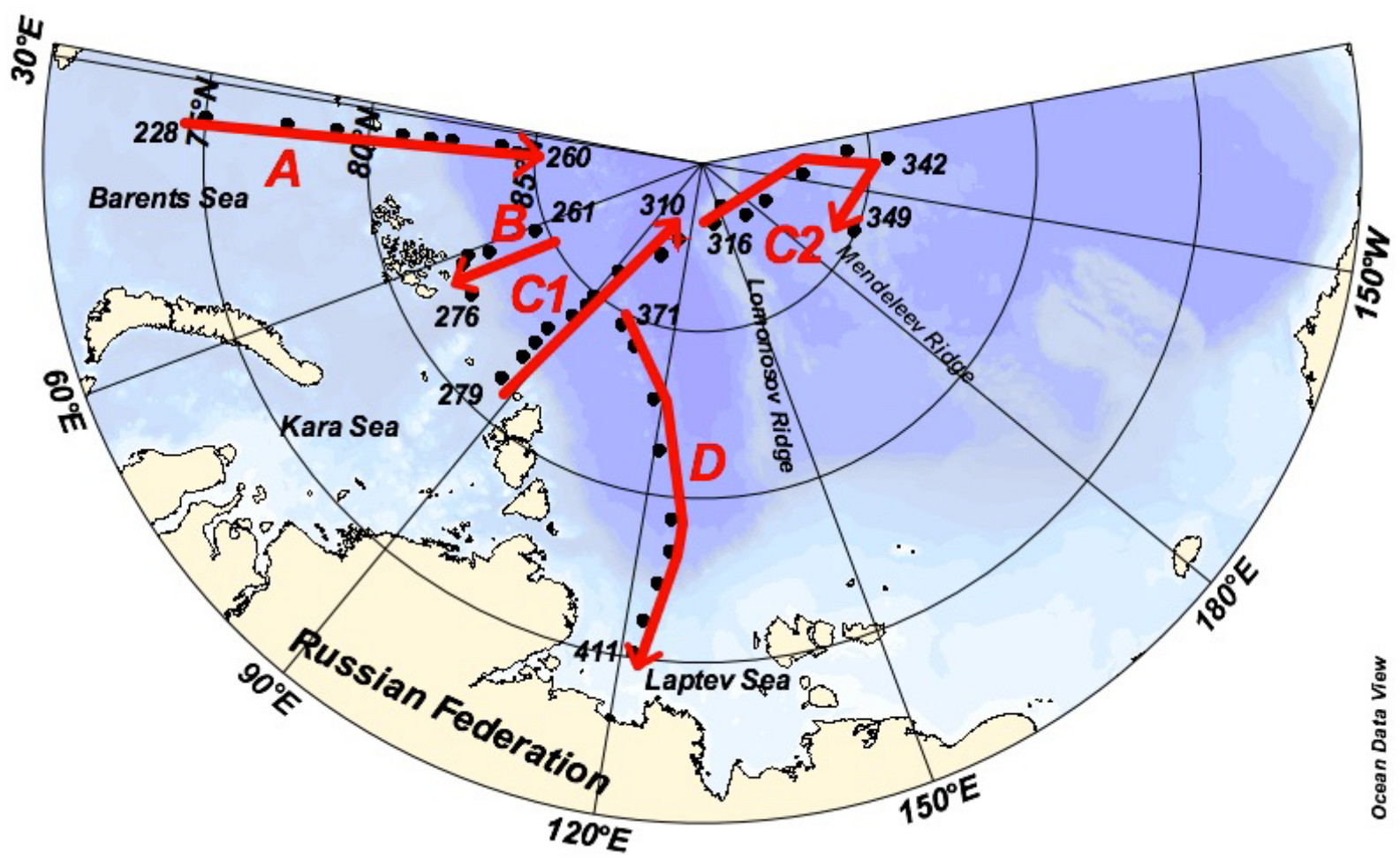

Fig. 1: Cruise map of R/V Polarstern cruise ARK-XXII/2 in 2007 (see table 1). Red arrows mark sections in the direction of travel. 


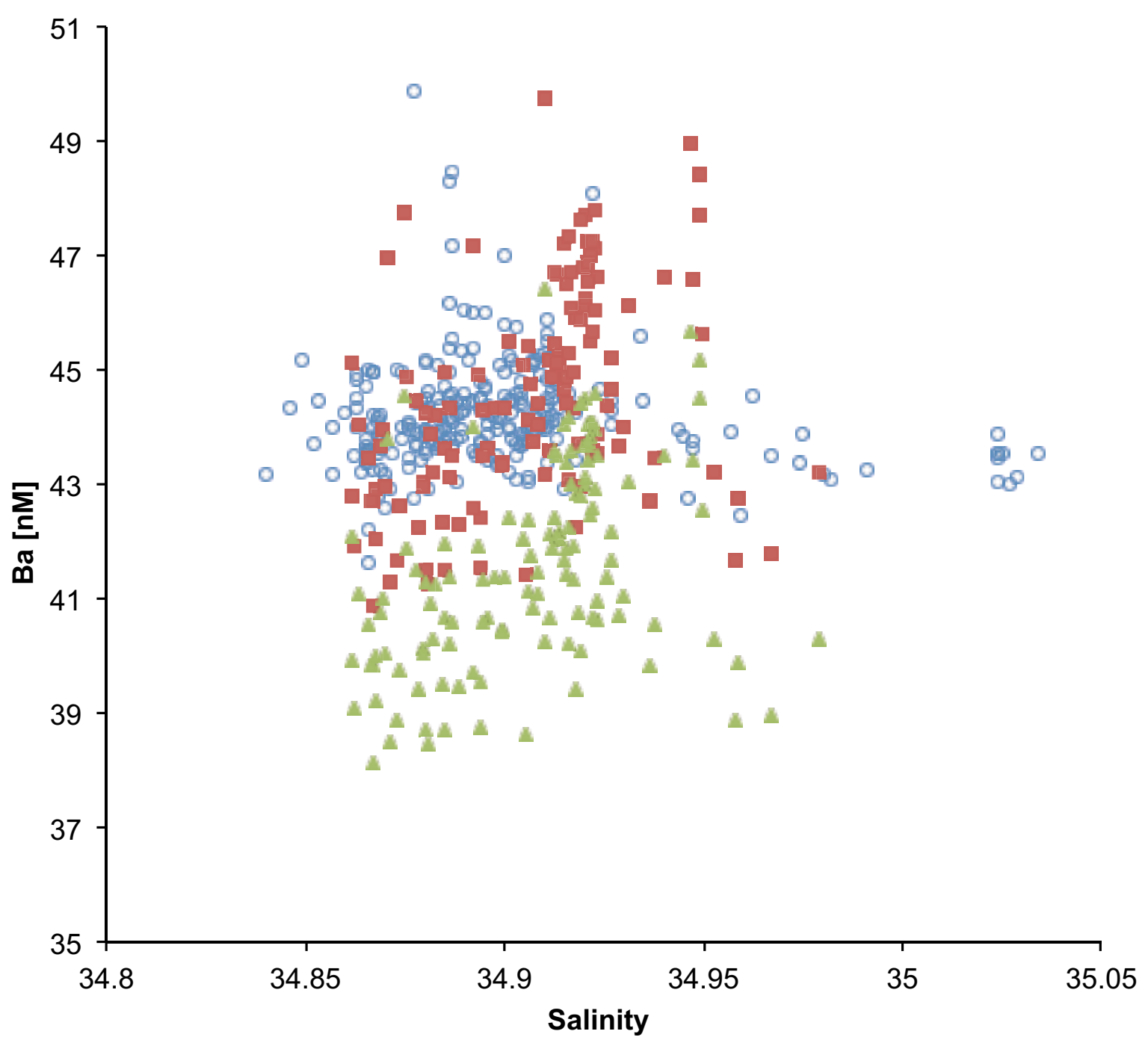

Fig. 2: Comparison of Ba/salinity systematics of all samples of salinities $>34.85$ of Abrahamsen and Falkner (personal communication) (blue circles) and those of our lab where we used two different standard types as absolute reference for calibrating the ${ }^{135} \mathrm{Ba}$ standard: commercial ICP MS standards (red squares) and natural waters (green triangles). Calibration with commercial standards results in $7.2 \%$ higher absolute concentrations of dissolved $\mathrm{Ba}$ than calibration with natural waters and better reproduces the data from Abrahamsen et al. (2009) and previous publications on Ba in the Arctic (cf. Falkner et al., 1993; 1994; Guay and Falkner 1997; 1998). 

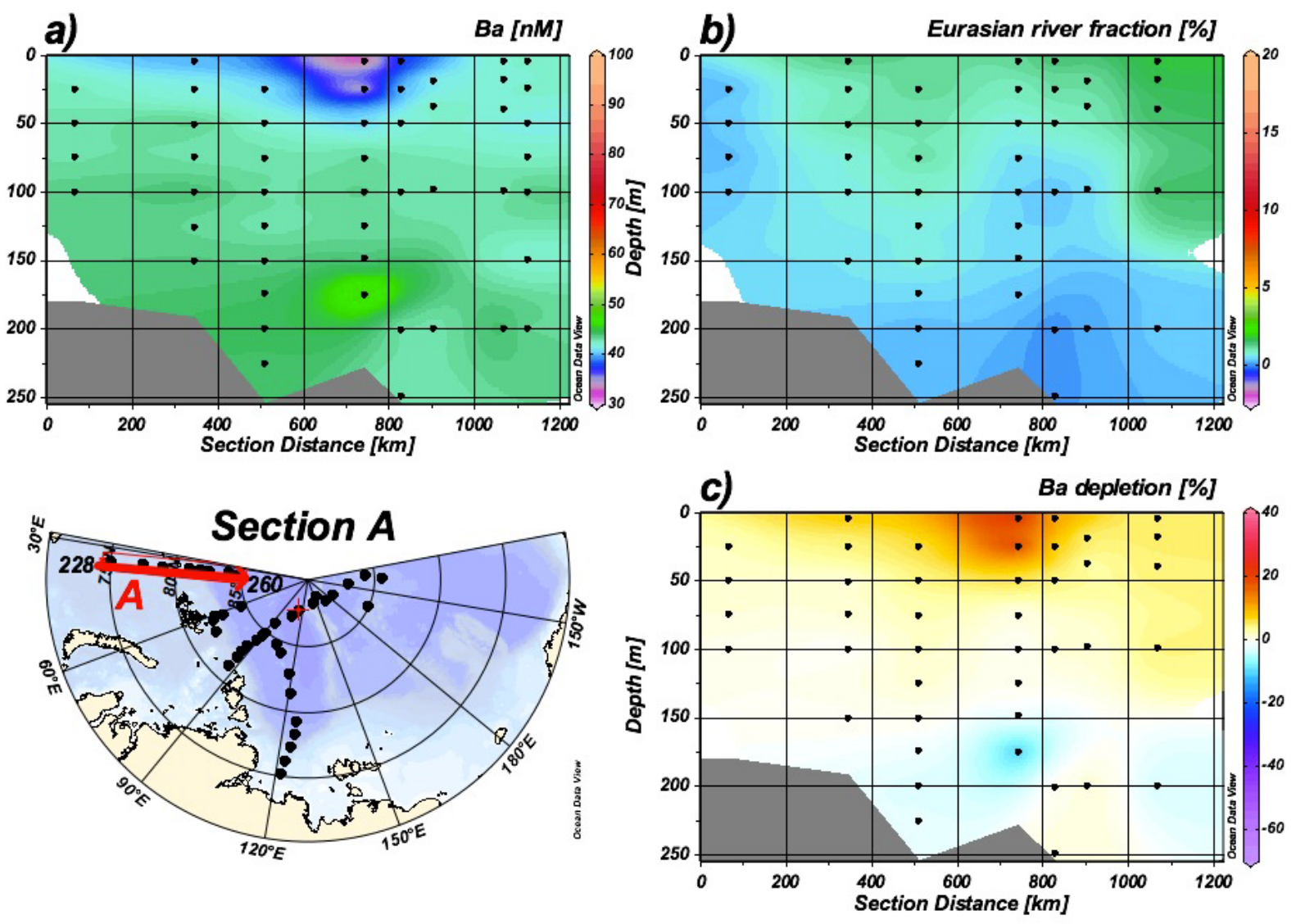

Fig. 3: Section A from the Barents Sea to the Nansen Basin: a) Concentrations of dissolved $\mathrm{Ba}[\mathrm{nM}]$; b) River water fraction [\%] from the solved mass balance system matching Eurasian runoff; c) Ba depletion with positive and negative values reflecting depletion and enrichment [\%] respectively. This has to be seen as a deficit or excess concentration of $\mathrm{Ba}$, based on the expected concentration $\mathrm{Ba}^{0}$. 

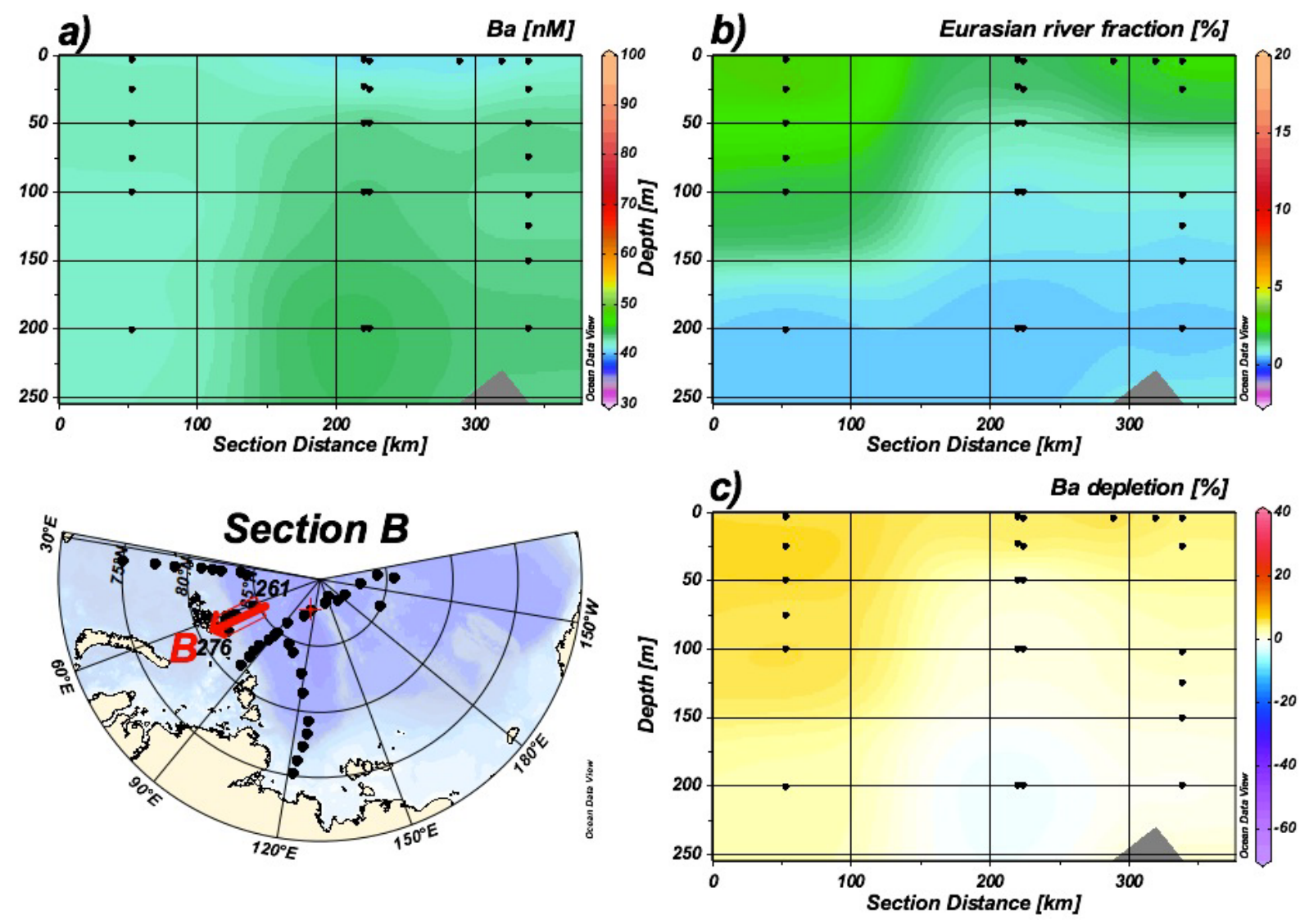

Fig. 4: Section B from the Nansen Basin to the Kara Sea slope (for details see fig. 3): a) Concentrations of dissolved $\mathrm{Ba}[\mathrm{nM}$ ]; b) fraction of Eurasian runoff [\%]; c) $\mathrm{Ba}$ depletion [\%]. 

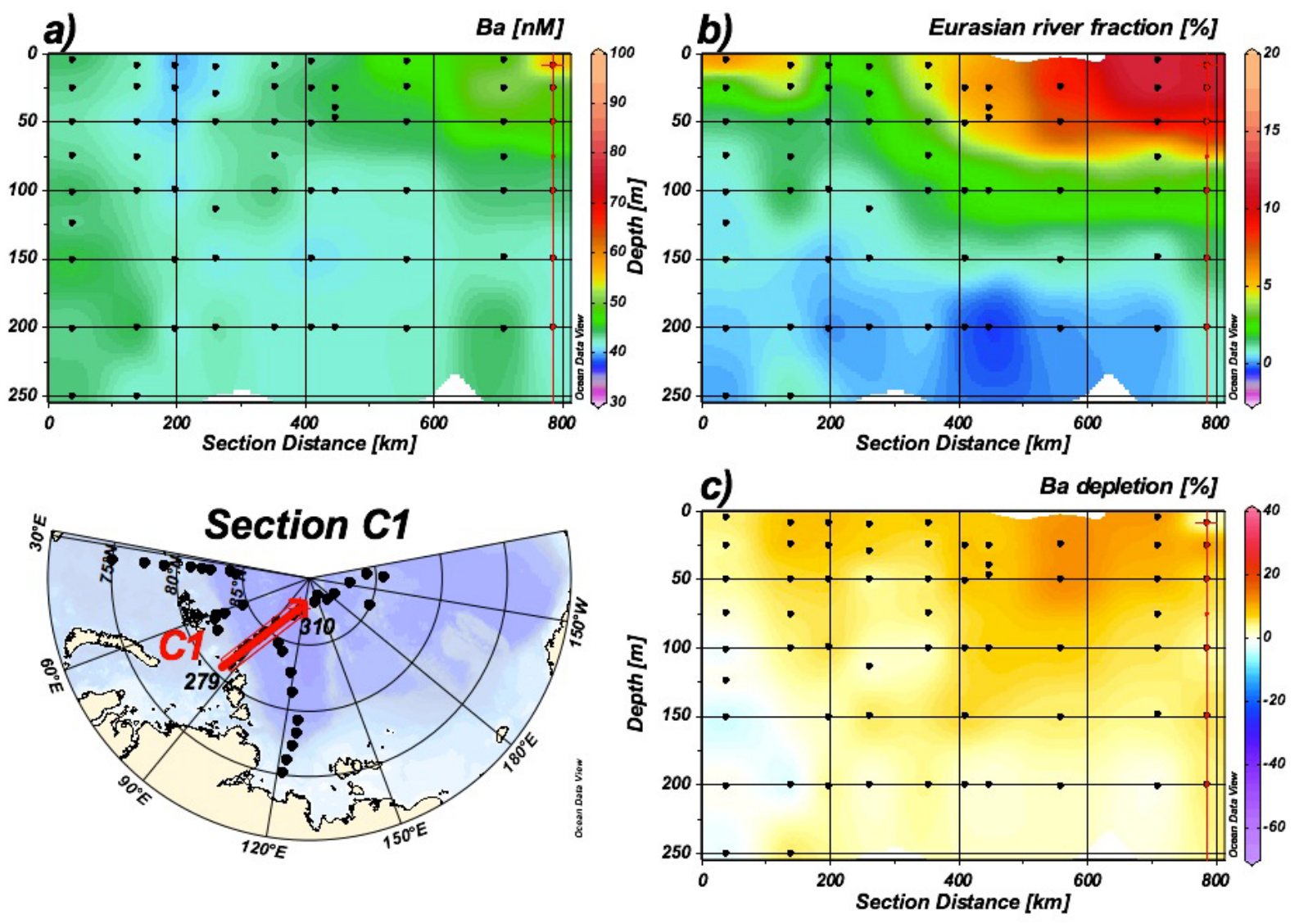

Fig. 5: Section $\mathrm{C} 1$ from the Kara Sea slope to the Lomonosov Ridge (for details see fig. 3): a) Concentrations of dissolved $\mathrm{Ba}$ [nM]; b) fraction of Eurasian runoff [\%]; c) Ba depletion [\%].
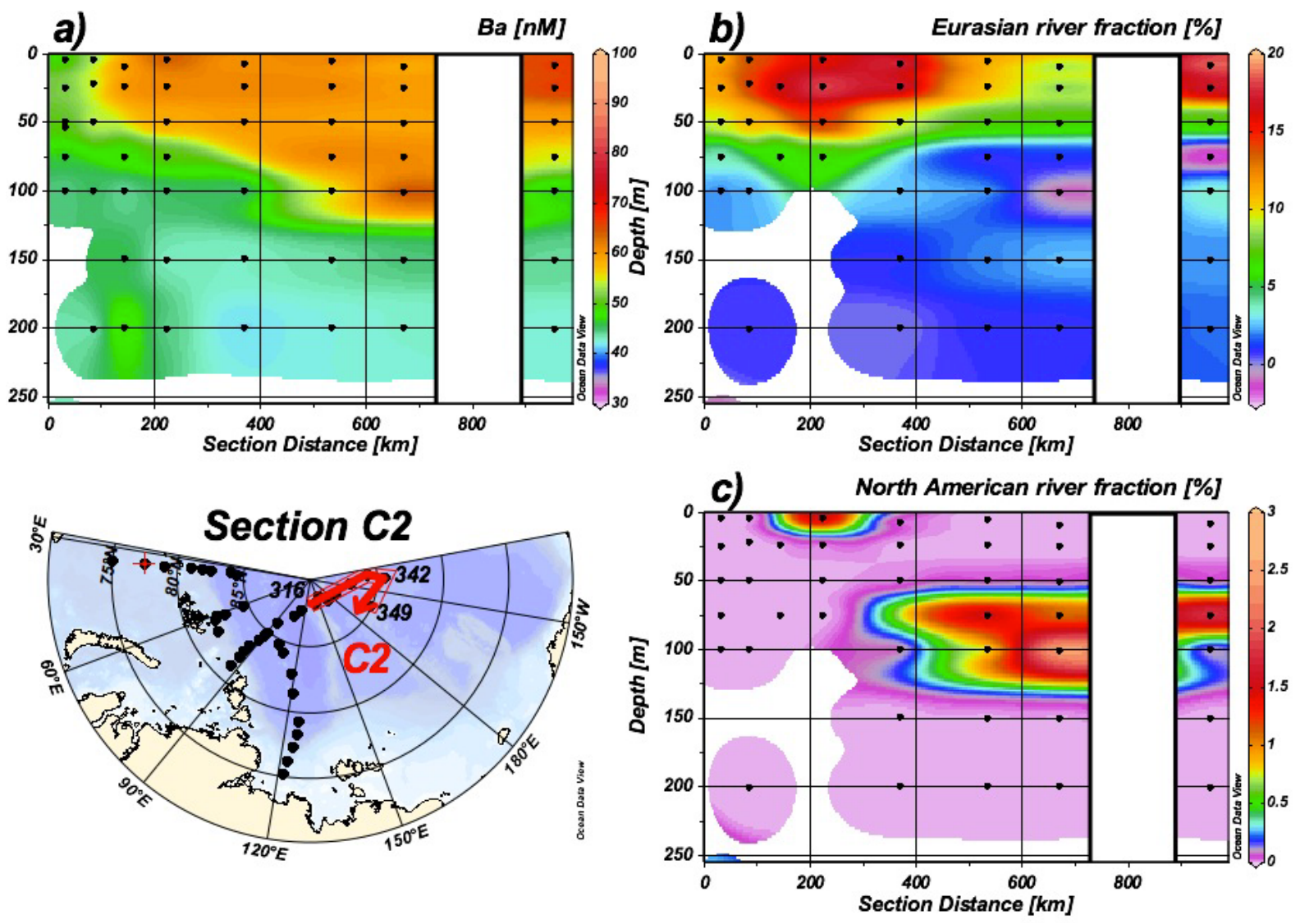
Fig. 6: Section C2 from the Lomonosov Ridge to the Alpha/ Mendeleyev Ridge (for details see fig. 3): a) Concentrations of dissolved $\mathrm{Ba}$ [nM]; b) fraction of Eurasian runoff [\%]; c) fraction of (calculated) NA runoff [\%]. Panels b) and c) here assume conservative behavior of $\mathrm{Ba}$. Fractions of Pacific water calculated using N/P signature.
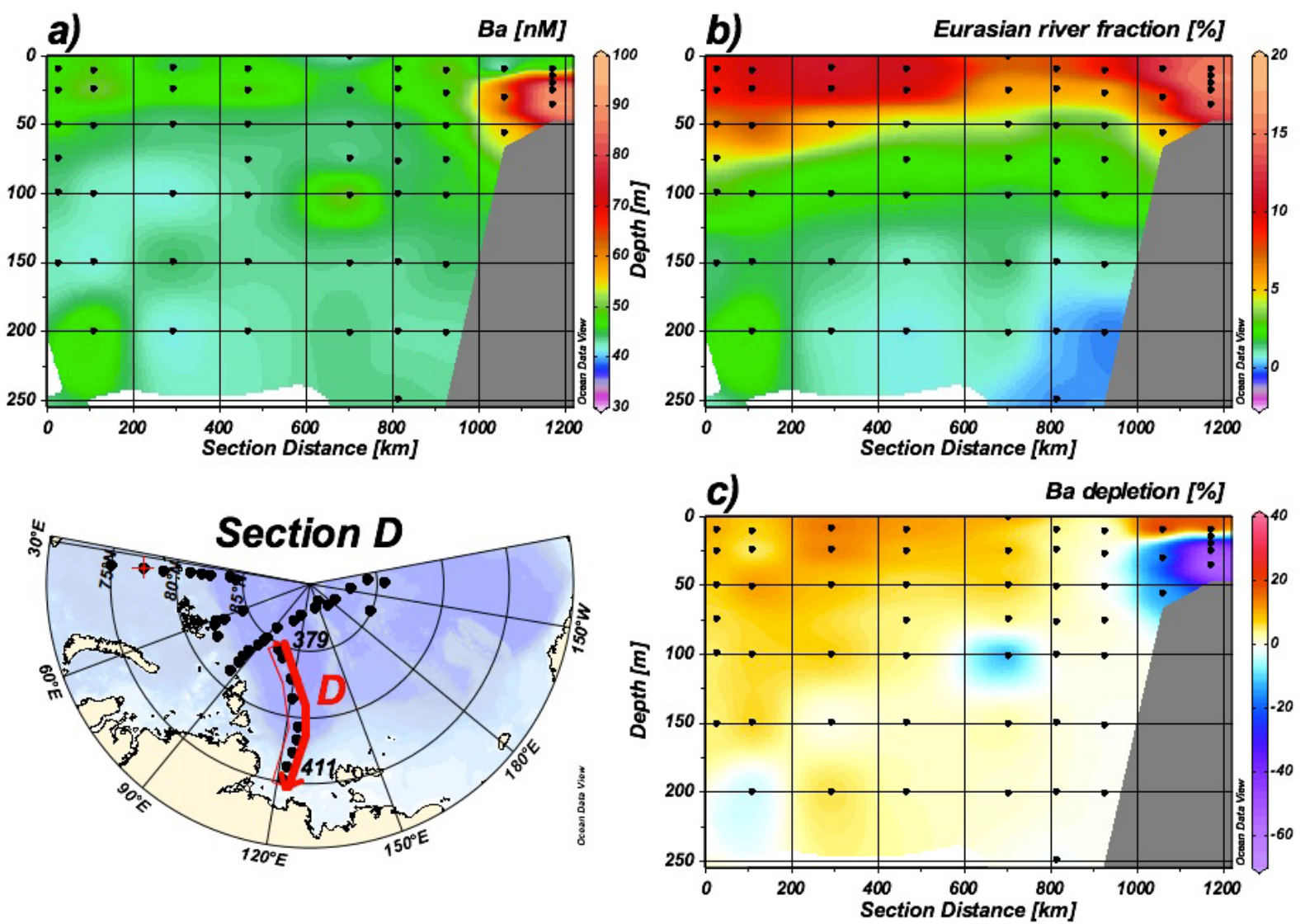

Fig. 7: Section D from the Eurasian Basin to the Laptev Sea (for details see fig. 3): a) Concentrations of dissolved $\mathrm{Ba}[\mathrm{nM}]$; b) fraction of Eurasian runoff [\%]; c) $\mathrm{Ba}$ depletion [\%]. 

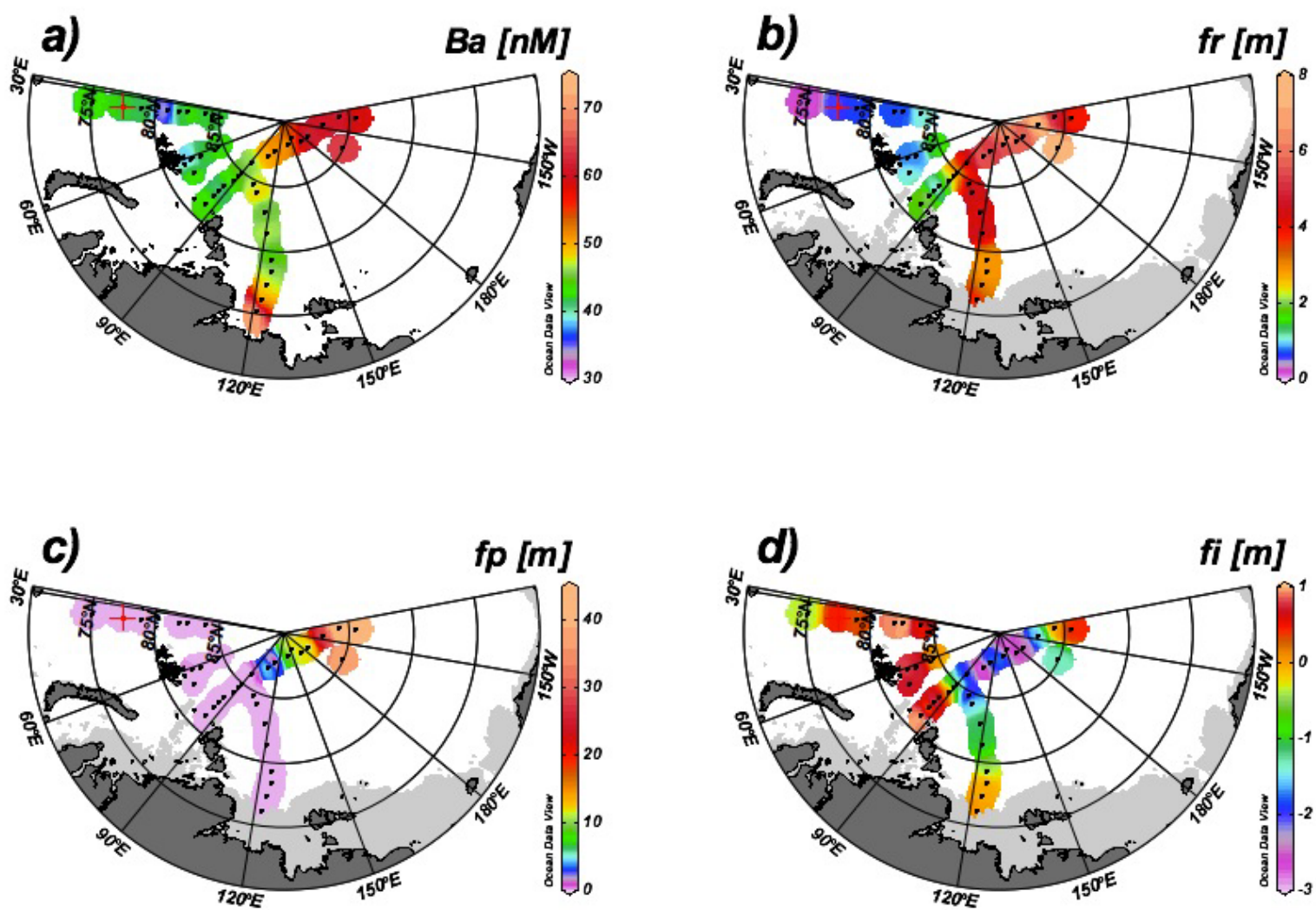

Fig. 8: Maps showing a) the average Ba concentrations in the upper $50 \mathrm{~m}, \mathrm{~b}$ ) the integrated height [m] in the upper $50 \mathrm{~m}$ of river water, c) of Pacific water, and d) of sea ice melt.

\section{Oxygen [mol/L]}

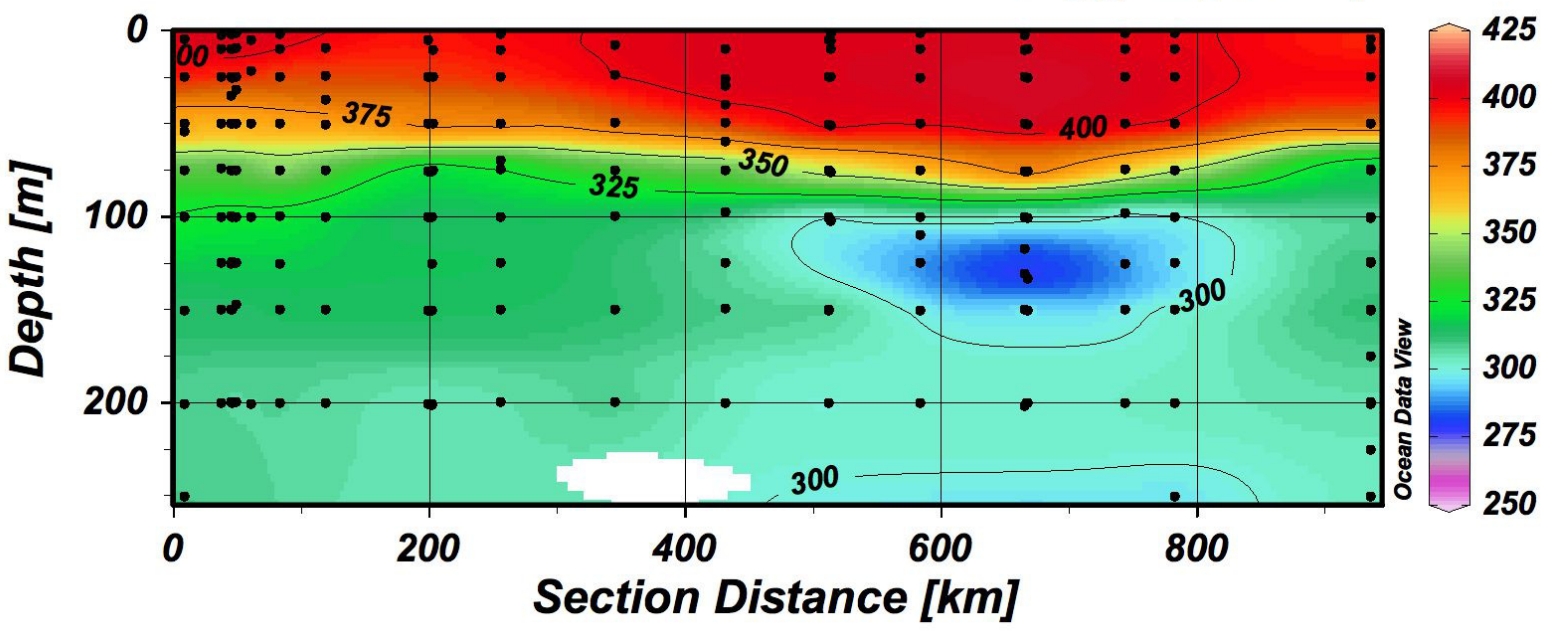

Fig. 9: Dissolved oxygen (Wisotzki, 2008) at section C2 (cf. fig. 6). An oxygen minimum is positioned at $120 \mathrm{~m}$ depth just below the observed maximum of $\mathrm{Ba}$ and silicate (cf. Middag et al., 2009). 